\title{
P2X2 and P2X5 Subunits Define a New Heteromeric Receptor with P2X7-Like Properties
}

\author{
Vincent Compan, ${ }^{1,2,3}$ Lauriane Ulmann, ${ }^{1,2,3}$ Olga Stelmashenko, ${ }^{4}$ Jean Chemin, ${ }^{1,2,3}$ Séverine Chaumont, ${ }^{1,2,3}$ \\ and Francois Rassendren ${ }^{1,2,3}$ \\ ${ }^{1}$ CNRS, UMR 5203, Institut de Génomique Fonctionnelle, ${ }^{2}$ INSERM, U661, and ${ }^{3}$ Universités de Montpellier 1 et 2, UMR 5203, F-34000 Montpellier, France, \\ and ${ }^{4}$ Faculty of Medical and Human Sciences, University of Manchester, Manchester, M13 9PT, United Kingdom
}

Ligand-gated ion channels are prototypic oligomeric membrane proteins whose stoichiometry determines their functional properties and subcellular localization. Deciphering the quaternary structure of such protein complexes is an arduous task and usually requires the combination of multiple approaches. ATP-gated P2X receptors are formed by the association of three subunits, but the quaternary arrangement of the seven P2X subunits at the plasma membrane remains poorly characterized. By combining bioluminescence resonance energy transfer, bifunctional fluorescence complementation and protein biochemistry, we developed an experimental approach that allows precise determination of rat $\mathrm{P} 2 \mathrm{X}$ receptor quaternary assembly. We found that $\mathrm{P} 2 \mathrm{X} 5$ subunits associate with $\mathrm{P} 2 \mathrm{X} 1, \mathrm{P} 2 \mathrm{X} 2$, and P2X4 subunits. We demonstrate that P2X5 and P2X2 subunits interact to form as yet uncharacterized heteromeric receptors with alternate stoichiometries, both present at the plasma membrane. $\mathrm{P} 2 \mathrm{X} 2 / 5$ receptors display functional properties such as pore dilatation, membrane blebbing, and phosphatidylserine exposure that were previously thought to be characteristic hallmarks of the P2X7 receptor. In mouse, P2X2 and P2X 5 subunits colocalize and physically interact in specific neuronal populations suggesting that other P2X receptors might contribute to cellular responses typically attributed to $\mathrm{P} 2 \mathrm{X} 7$ receptor.

\section{Introduction}

Ligand-gated channels are prototypic oligomeric membrane proteins formed by the association of a given number of the same subunit (homomeric channels) or of different subunits (heteromeric channels) (Taly et al., 2009). The subunit composition of ligand-gated channels defines not only their pharmacological properties but also their functional characteristics. However, deciphering the quaternary subunit assembly of channels can sometimes lead to controversial results.

$\mathrm{P} 2 \mathrm{X}$ receptors are ATP-gated channels with widespread tissue distribution and physiological functions (Surprenant and North, 2009). Seven different P2X subunits (P2X1-7) have been identified; they all share the same membrane topology with two transmembrane segments linked by a large ectodomain, and the $\mathrm{N}$ and $\mathrm{C}$ termini are intracellular. Early studies, confirmed by the resolution of the crystal structure of a P2X receptor, proposed that three subunits assemble to form P2X receptors (Nicke et al., 1998; Kawate et al., 2009). Of the seven rat recombinant P2X subunits, five assemble to form functional homomeric receptors in heterologous expression systems, whereas P2X5 receptors are poorly

Received Dec. 20, 2011; revised Jan. 24, 2012; accepted Feb. 2, 2012.

Author contributions: V.C., L.U., S.C., and F.R. designed research; V.C., L.U., O.S., J.C., S.C., and F.R. performed research; V.C., L.U., O.S., J.C., S.C., and F.R. analyzed data; V.C. and F.R. wrote the paper.

This work was supported by CNRS and INSERM. V.C. was supported by fellowships from Ministère de la Recherche et des Nouvelles Technologies and Association pour la Recherche sur le Cancer, $0 . S$. was supported by the Wellcome Trust. We thank Drs. Ayoub and Charnet for their help with BRET and electrophysiological experiments, and Dr. Durroux for reading this manuscript.

Correspondence should be addressed to Francois Rassendren, Institut de Génomique Fonctionnelle, CNRS UMR5203, 141 rue de la Cardonille, 34094 Montpellier, France. E-mail: francois.rassendren@igf.cnrs.fr.

DOI:10.1523/JNEUROSCI.6332-11.2012

Copyright $\odot 2012$ the authors $\quad 0270-6474 / 12 / 324284-13 \$ 15.00 / 0$ functional and P2X6 subunits are unable to self-associate (North and Surprenant, 2000; Roberts et al., 2006). Different P2X subunits can also associate as heteromeric receptors. Based on coexpression of recombinant subunits, 13 potential heteromeric $\mathrm{P} 2 \mathrm{X}$ receptors have been proposed (Torres et al., 1999), some being expressed at the plasma membrane (Aschrafi et al., 2004). However, to date, $\mathrm{P} 2 \mathrm{X} 2 / 3$ and $\mathrm{P} 2 \mathrm{X} 1 / 5$ receptors are the only unambiguously characterized heteromeric $\mathrm{P} 2 \mathrm{X}$ receptors in native tissue (Brederson and Jarvis, 2008). The $\mathrm{P} 2 \mathrm{X} 2 / 3$ receptor was initially identified in sensory neurons through its unique pharmacological and biophysical profiles, which were recapitulated in a recombinant system (Lewis et al., 1995; Radford et al., 1997). Similarly, in submucosal arterioles and cortical astrocytes, ATPinduced currents display the same biophysical and pharmacological profiles that are observed in HEK cells cotransfected with P2X1 and P2X5 subunits (Haines et al., 1999; Lê et al., 1999; Surprenant et al., 2000; Lalo et al., 2008).

As with other ligand-gated channels, the experimental strategies required to investigate $\mathrm{P} 2 \mathrm{X}$ subunit assembly should lead to the clear determination of the nature of the interactions between subunits and/or receptors, to the exact definition of the stoichiometry of these interactions, and ultimately provide a demonstration of the existence of these interactions in native conditions.

In this study, we used a combination of cell surface assay, bioluminescence resonance energy transfer (BRET), bimolecular fluorescence complementation (BiFC), and biochemical approaches to analyze the interactions existing between $\mathrm{P} 2 \mathrm{X}$ subunits. We found that P2X5 subunits can interact with $\mathrm{P} 2 \mathrm{X} 1$, $\mathrm{P} 2 \mathrm{X} 2$, or P2X4 subunits at the plasma membrane. We demonstrate that $\mathrm{P} 2 \mathrm{X} 2$ and $\mathrm{P} 2 \mathrm{X} 5$ subunits associate in a new heterotri- 
meric receptor showing two alternate stoichiometries. We provide evidence that $\mathrm{P} 2 \mathrm{X} 2 / 5$ receptors are expressed in specific regions of the CNS, and that $\mathrm{P} 2 \mathrm{X} 2 / 5$ receptors have functional properties that were previously thought to be unique to the P2X7 receptor.

\section{Materials and Methods}

cDNA cloning, epitope tagging, and site-directed mutagenesis. The different $\mathrm{P} 2 \mathrm{X}$ cDNAs carrying extracellular tags and mutations were described previously (Chaumont et al., 2004). The hemi-yellow fluorescent protein (YFP-N and YFP-C), RAMP1-YC, and CRLR-YN were gifts from Dr. M. Bouvier (University of Montreal, Montreal, Canada) (Héroux et al., 2007); YC3.1 (CAM) was a gift from Dr. B. Khakh (University of California Los Angeles, Los Angeles, CA) (Richler et al., 2008); and Renillia luciferase (Rluc) and PAR-1-YFP were gifts from Dr. Ayoub (Institut de Genomique Fonctionnelle, CNRS, Montpellier, France) (Ayoub et al., 2007). All reporter proteins were PCR inserted in frame at the C-terminal tail of P2X subunits.

Cell culture and transfections. Human Embryonic Kidney 293 cells (HEK) were maintained as described previously (Chaumont et al., 2004). Transfections were performed using Lipofectamine 2000 (Invitrogen) according to the manufacturer's recommendation; $4 \mathrm{~h}$ after transfection, cells were split and incubated at $37^{\circ} \mathrm{C}$ for $36-48 \mathrm{~h}$ in DMEM supplemented with glutamine, fetal calf serum, and antibiotics.

Bioluminescence resonance energy transfer and bimolecular fluorescent complementation. Transfected HEK cells were plated in two independent 96-well polyornithine-coated plates. Thirty-six hours later, cells were washed twice with calcium and magnesium-supplemented PBS, and coelenterazine $\mathrm{H}$ (Invitrogen) was added at a final concentration of $5 \mu \mathrm{M}$. Emitted light was collected at $2 \mathrm{~Hz}$ using a Mithras LB 940 plate reader (Berthold Technologies) using two filter settings (Rluc filter, $485 \pm 20$ $\mathrm{nm}$; and YFP filter, $530 \pm 25 \mathrm{~nm}$ ). The BRET signal corresponds to the ratio of YFP/Rluc signals. Values were corrected by subtracting the background BRET signal measured in the absence of YFP constructs. For BRET titration curve experiments, cells were transfected with a fixed amount of Rluc fusion cDNA and increasing amounts of YFP fusion cDNA. To control for relative expression levels of donor and acceptor proteins, total luminescence and fluorescence were measured independently in separate plates. BRET values were then plotted as a function of the total fluorescence/luminescence ratios (YFP/Rluc). For kinetic studies, after baseline acquisition, $100 \mu \mathrm{M}$ ATP was applied to individual wells through the Mithras automatic injection system. For BRET/BiFC experiments, cells were incubated at $30^{\circ} \mathrm{C}$ for $12 \mathrm{~h}$ before the reading to promote the complementation between hemi-YFP. Total fluorescence, BRET signal, and YFP recomplementation were measured as described above.

Chemiluminescent assay. ELISA assay was performed as described by Chaumont et al. (2004). Briefly, transfected cells were PFA-fixed and Triton-permeabilized (or not), blocked with PBS with $1 \%$ fetal calf serum, and incubated for $30 \mathrm{~min}$ with anti-Flag M2 antibody directly coupled to HRP (1/4000) (Sigma). Luminescence was measured using Supersignal femto substrate (Pierce) and quantified in a Victor 2 luminometer (PerkinElmer). Surface expression was calculated as the ratio of the signal obtained in nonpermeabilized cells to the signal obtained for permeabilized cells.

Plasma membrane protein biotinylation, immunoprecipitation, and Western blotting. Transfected HEK cells were washed twice in ice-cold PBS containing $1 \mathrm{mM} \mathrm{CaCl}_{2}$ and $0.5 \mathrm{~mm} \mathrm{MgCl}_{2}$ (PBS-CM). Cell surface proteins were labeled using $1 \mathrm{mg} / \mathrm{ml}$ sulfo-NHS-LC-Biotin (Pierce) for 30 min at $4^{\circ} \mathrm{C}$ in biotinylation buffer (in mm: $10 \mathrm{H}_{3} \mathrm{BO}_{3}, 140 \mathrm{NaCl}, \mathrm{pH}$ 8.8). Cell lysis was performed for $30 \mathrm{~min}$ at $4^{\circ} \mathrm{C}$ under agitation in lysis buffer [in mM: 20 HEPES, $100 \mathrm{NaCl}, 5$ EDTA, 1\% NP40, pH 7.4, and protease inhibitors mixture (Roche Diagnostic)]. Lysates were centrifuged $\left(16,000 \times g, 10 \mathrm{~min}, 4^{\circ} \mathrm{C}\right)$ and the supernatant was collected. For immunoprecipitation, $500 \mu \mathrm{g}$ of protein was incubated on a rotating wheel with either anti-HA (12CA5) or anti-Myc (9E10) antibodies and then with protA-Sepharose beads $\left(4^{\circ} \mathrm{C}, 1 \mathrm{~h}\right)$. After washes in lysis buffer, bound proteins were eluted by two incubations with $200 \mu \mathrm{g} / \mathrm{ml}$ Myc or
HA peptides. Proteins were resolved by SDS-PAGE, transferred to nitrocellulose membranes and visualized using either streptavidin-HRP (1/ 50,000, Pierce) or appropriate primary antibodies: HA 1/2000 (clone 12CA5, Roche), Myc 1/5000 (clone 9E10, Santa Cruz Biotechnology), GFP 1/2500 (Torrey Pines), EE 1/2000 (Bethyl Laboratories), and SuperSignal West Pico substrate (Pierce).

Cross-linking in vivo of plasma membrane protein. Cross-linking was performed as described above for plasma membrane protein biotinylation, except that BS3 (Pierce) was used at a final concentration of $2 \mathrm{~mm}$. After cross-linking, cells were lysed and proteins separated by SDS/ PAGE. Cross-linked P2X subunits were revealed by Western blotting using anti-Myc or anti-GFP antibodies.

PFO-PAGE. Native gels were performed as described previously (Ramjeesingh et al., 1999). Membrane solubilization was performed in lysis buffer as described above for Western blotting, and $2 \times$ loading buffer was added [100 mm Tris base, $1 \%$ (w/v) NaPFO, 20\% (v/v) glycerol, $0.005 \%$ Bromophenol Blue; $\mathrm{pH} 8.0$ with $\mathrm{NaOH}$ ]. Electrophoresis was performed at $4^{\circ} \mathrm{C}$ on polyacrylamide gel in $\mathrm{PFO}$ containing running buffer [ $25 \mathrm{~mm}$ Tris, $192 \mathrm{~mm}$ glycine and $0.5 \%$ (w/v) PFO; pH 8.5 with $\mathrm{NaOH}$ ]. P2X subunits were revealed as described above. Molecular weight markers apoferritin $(440 \mathrm{kDa}), \beta$-amylase $(200 \mathrm{kDa})$, alcohol dehydrogenase $(150 \mathrm{kDa})$, and bovine serum albumin $(66 \mathrm{kDa})$ were diluted in $2 \times$ loading buffer containing $\mathrm{NaPFO}$ and separated by electrophoresis as described above. Relative migration of protein standards was detected by Ponceau red staining before membrane blocking.

Coimmunoprecipitation of native $\mathrm{P} 2 \mathrm{X} 5$ and $\mathrm{P} 2 \mathrm{X} 2$ proteins. Immunoprecipitation of native $\mathrm{P} 2 \mathrm{X}$ subunits was performed from membrane protein extracts as previously described (Chaumont et al., 2008). After preclearing, solubilized membrane proteins were incubated overnight at $4^{\circ} \mathrm{C}$ with either rabbit anti-P2X5 [a gift from Dr. Mark Voigt (Schwiebert et al., 2002)] or rabbit anti-P2X2 (Alomone Labs), and incubated $1 \mathrm{~h}$ at $4^{\circ} \mathrm{C}$ with $20 \mu \mathrm{l}$ of proteinA-Sepharose beads. Beads were washed $3 \times 5$ min with solubilization buffer, and bound proteins were eluted with Laemmli sample buffer. Immunoprecipitates were detected by Western blotting as described above, except that Rabbit TrueBlot (eBioscience) secondary antibody was used for detection of P2X5, according to the manufacturer's instruction. Anti-P2X2 and anti-P2X5 were used at 1/500 to reveal the corresponding proteins.

Immunocytochemistry on HEK cells. Transfected HEK cells were plated on polyornithine-coated $25 \mathrm{~mm}$ glass coverslips and maintained for 2-3 $\mathrm{d}$ in culture. For in vivo labeling of tagged receptors, cells were incubated directly in the culture medium containing anti-Myc antibody (9E10, $1 / 1000$ ), for $45 \mathrm{~min}$ at $37^{\circ} \mathrm{C}$. After washes, cells were fixed in $4 \%$ paraformaldehyde, $4 \%$ sucrose PBS-CM for $5 \mathrm{~min}$, washed with a solution of 0.1 $\mathrm{M}$ glycine in PBS-CM, and incubated with fluorescent secondary antibody for $45 \mathrm{~min}$. After extensive washing, coverslips were mounted and viewed with a Leica DMRA2 fluorescent microscope.

Immunocytochemistry on native tissue. For experiments on dorsal root ganglia (DRGs), mice of either sex were anesthetized with pentobarbital (300 mg/kg), and DRGs from L6, L5, L4 were dissected and fixed $2 \mathrm{~h}$ in $4 \%$ paraformaldehyde. For spinal cord and brainstem, mice were transcardiacally perfused with $4 \%$ paraformaldehyde; postfixation was performed in the same solution at $4^{\circ} \mathrm{C}$ overnight. Tissue sections $(40 \mu \mathrm{m})$ were made with a vibratome, washed with PBS, and blocked for $1 \mathrm{~h}$ in PBS containing $10 \%$ BSA, $0.1 \%$ Triton. Sections were incubated overnight at $4^{\circ} \mathrm{C}$ in PBS, $0.1 \%$ Triton X100 with guinea pig anti-P2X2 (1/ $1000)$ (Neuromics), and rabbit anti-P2X5 (1/500). After washing, slices were incubated for $4 \mathrm{~h}$ with the corresponding secondary antibody. After washing, sections were mounted in mowiol (Calbiochem). Images were acquired on a Biorad MRC 1024 laser-scanning confocal microscope.

Video-microscopy. Time-lapse video-microscopy of membrane blebbing was performed on transfected HEK cells plated on $35 \mathrm{~mm}$ glassbottom dishes (Fluorodish, WPI) precoated with polyornithine. Experiments were performed in DMEM-HEPES culture medium in a temperature-regulated chamber at $37^{\circ} \mathrm{C}$ using a Zeiss Axiovert $2000 \mathrm{M}$ equipped with a Cool Snap Roper Scientific HQ camera and a $\times 63$ objective. Image acquisition started $2 \mathrm{~min}$ before perfusion with $100 \mu \mathrm{M}$ ATP and lasted for $5 \mathrm{~min}$, with an image acquisition rate of $0.5 \mathrm{~Hz}$. 
Dye uptake. Yo-Pro-1 uptake: Transfected HEK cells were plated as described above. Cells were washed and then incubated for $5 \mathrm{~min}$ before video-microscopy in NMDG medium (in mm: $147 \mathrm{NMDG}, 0.3 \mathrm{CaCl}_{2}, 2 \mathrm{KCl}, 1 \mathrm{MgCl}_{2}, 10$ HEPES, 12 glucose, $\mathrm{pH}$ 7.4) containing $2 \mu \mathrm{M}$ Yo-Pro-1 (Invitrogen). Some experiments were performed in physiological medium containing $147 \mathrm{~mm} \mathrm{NaCl}$ instead of NMDG. The Metafluor Imaging system (Molecular Devices) was used for fluorescence acquisition and analysis of individual cells. After $30 \mathrm{~s}$ of baseline acquisition, cells were perfused with 10 or $100 \mu \mathrm{M}$ ATP for the following $3 \mathrm{~min}$. Images were acquired every $300 \mathrm{~ms}$ except where indicated. Fluorescence was excited at $480 \mathrm{~nm}$ by illumination through $\times 20$ waterimmersion objective and detected above 510 $\mathrm{nm}$ with a CCD camera. Results are expressed as the mean of all recorded cells $(>50)$ after background subtraction. Ethidium bromide $(\mathrm{EtBr})$ uptake experiments were performed as described above except that fluorescence was detected at $590 \mathrm{~nm}$ after excitation at 540 $\mathrm{nm}$. Cells incubated in $\mathrm{NaCl}$-based solution and $\mathrm{EtBr}(25 \mu \mathrm{M})$ were stimulated with 100 $\mu \mathrm{M}$ or $5 \mathrm{~mm}$ ATP. Images were acquired every $20 \mathrm{~s}$ using a Zeiss Axiovert 25 microscope equipped with a Zeiss Axiocam HRc camera. Fluorescence variations were quantified using ImageJ software (http://rsb.info.nih.gov/ij/).

Annexin- $V$ staining. P2X-YFP transfected HEK cells seeded on polyornithine-coated glass coverslips were stimulated with the appropriate ATP concentration for $2 \mathrm{~min}$ in normal culture medium, rinsed with PBS, and incubated for $5 \mathrm{~min}$ with annexin-V-Cy3 according to the manufacturer's instruction (Biovison). After washing, cells were fixed and the coverslips mounted and viewed with a Leica DMRA2 fluorescent microscope.

Electrophysiology. For Xenopus laevis oocyte experiments, rat $\mathrm{P} 2 \mathrm{X} 2$ and $\mathrm{P} 2 \mathrm{X} 5 \mathrm{cDNAs}$ were linearized and in vitro transcribed using SP6 polymerases (Mmessage-machine; Ambion). Final RNA concentration was adjusted to $1 \mu \mathrm{g} /$ $\mu \mathrm{l}$. A 1:3 mixture of $\mathrm{P} 2 \mathrm{X} 2$ and $\mathrm{P} 2 \mathrm{X} 5 \mathrm{cRNAs}$ was used to favor the expression of $\mathrm{P} 2 \mathrm{X} 5$ subunits over that of P2X2. P2X2 cRNA was diluted with water accordingly. cRNA was injected into freshly isolated Xenopus oocytes. Two to three days after injection, currents were recorded under two-electrode voltage-clamp using a GeneClamp 500 amplifier (Molecular Devices) and digitized at $500 \mathrm{~Hz}$. Current and voltage electrodes $(1-1.5 \mathrm{M} \Omega)$ were filled with $3 \mathrm{M} \mathrm{KCl}$, and the membrane potential was clamped at $-60 \mathrm{mV}$. Oocytes were perfused at a flow rate of $5 \mathrm{ml} / \mathrm{min}$ with ND96 solution containing in mм: $98 \mathrm{NaCl}, 2 \mathrm{KCl}, 1.8 \mathrm{CaCl}_{2}, 1 \mathrm{MgCl}_{2}, 5$ HEPES, pH 7.4. NMDG recording solution contained in mM: $98 \mathrm{NMDG}, 2 \mathrm{KCl}, 2 \mathrm{MgCl}_{2}, 5$ HEPES, $\mathrm{pH}$ 7.4. All drugs (Sigma-Aldrich) were applied at their final concentration using a homemade computer-driven valve system. Current-voltage relations were obtained by applying $200 \mathrm{~ms}$ voltage ramps from -100 to $+60 \mathrm{mV}$ at $1 \mathrm{~Hz}$; reversal potentials were determined from the $I-V$ relationship using Clampfit software. Dose-response curves were fitted to the Hill sigmoid equation, and $\mathrm{EC}_{50}$ values were determined by nonlinear regression analysis (Prism, GraphPad). Statistical comparisons were
B
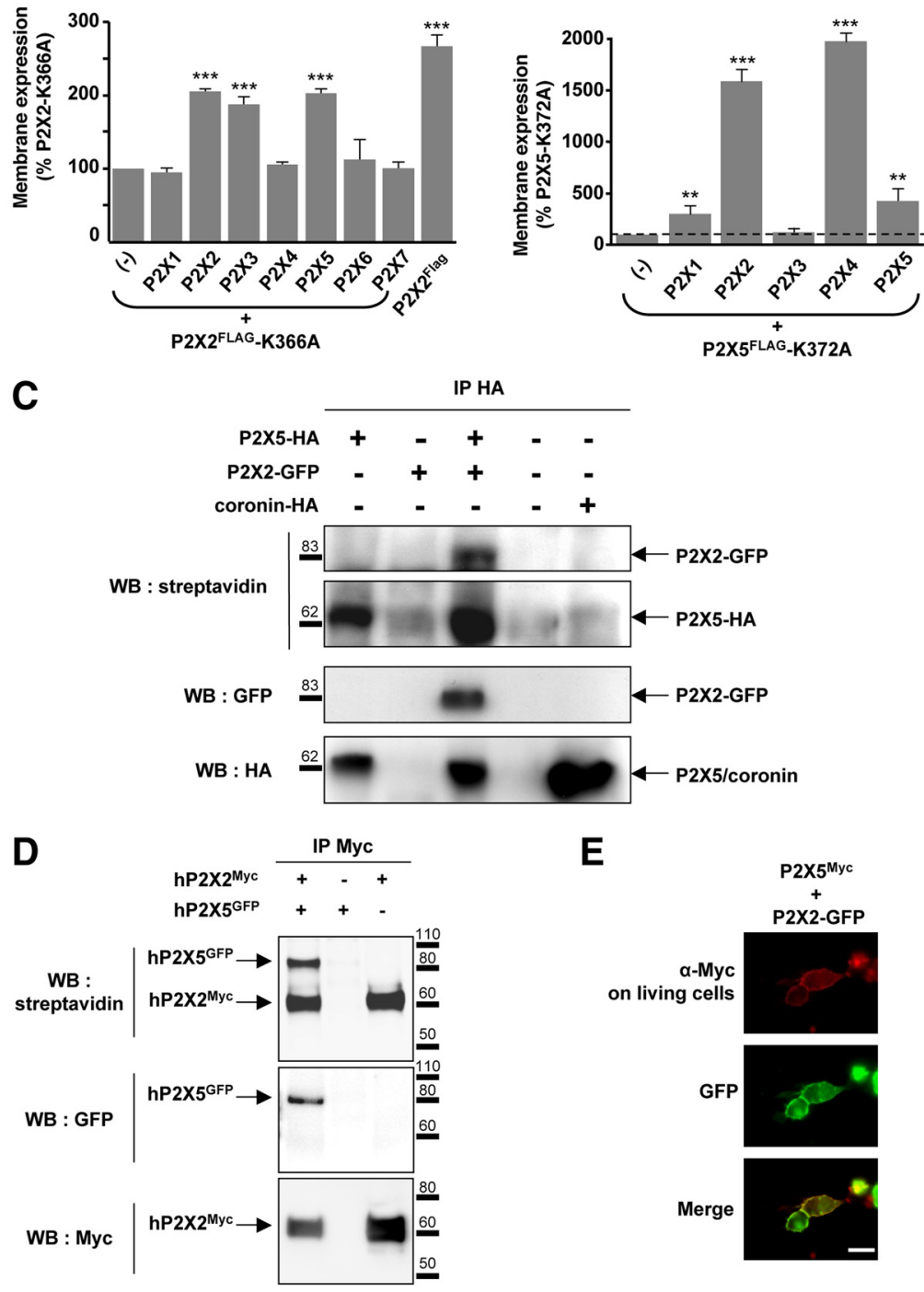

Figure 1. $P 2 X 5$ subunits interact with $P 2 X 2$ subunits at the plasma membrane. $A$, Rescue of cell surface expression of the P2X2-K366A trafficking deficient mutant by other subunits. P2X2-K366A carrying a Flag tag in the extracellular loop was expressed alone or in combination with each of the seven wild-type P2X subunits. Membrane expression was measured using a chemiluminescent assay. Cell surface expression of $P 2 X 2-K 366 A$ is rescued upon coexpression with $P 2 X 2, P 2 X 3, P 2 X 4$, and P2X5 subunits. $\boldsymbol{B}$, Membrane detection of the $P 2 X 5-K 372 A$ mutant carrying an extracellular Flag tag is increased when coexpressed with $P 2 X 1, P 2 X 2$, and $P 2 X 4$ and $P 2 X 5$ subunits. Note that because the surface expression of P2X5-K372 mutant is very low compared withP2X2-K366A, the changes appear much higher. Results are shown as mean \pm SEM of at least three independent experiments. ${ }^{* *} p<0.01,{ }^{* * *} p<0.005$, Student's $t$ test. C, P2X5 subunits interact with P2X2 at the plasma membrane. P2X5 carrying an extracellular HA tag was expressed alone or in combination with P2X2-GFP. Immunoprecipitation was performed after labeling living cells with sulfo-NHS-LC-biotin. Top, Biotinylated protein fraction after HA immunoprecipitation detected with streptavidinHRP. Middle and bottom, Detection of coimmunoprecipitated GFP and HA tagged-proteins, respectively. Coronin was used as a control for cell permeabilization. D, Human P2X2 and P2X5 subunits interact at the plasma membrane. Experiments were carried as described above, except that human P2X2-Myc and human P2X5-GFP CDNAs were used. $\boldsymbol{E}$, Immunodetection of P2X5 in living cells. HEK cells were transfected with P2X5 ${ }^{\text {Myc }}$ subunits carrying an extracellular Myc tag and P2X2-GFP. Immunostaining of P2X5 ${ }^{\text {Myc }}$ subunits (red) was performed by incubation of Myc antibodies on living cells; P2X2 subunits (green) were revealed through GFP fluorescence. Scale bar, $10 \mu \mathrm{m}$.

assessed using Student's $t$ test. The differences were considered significant for $p<0.05$

Whole-cell recordings of HEK cells were performed at room temperature $24-48 \mathrm{~h}$ after transfection, with a patch-clamp amplifier (Axopatch 200B) using pCLAMP9 software (Molecular Devices), at a holding potential of $-60 \mathrm{mV}$. All data were analyzed using pCLAMP9 and GraphPad Prism (GraphPad) software.

For rescue of $\mathrm{P} 2 \mathrm{X}$ trafficking deficient subunits, the extracellular solution contained in mM: $147 \mathrm{NaCl}, 2 \mathrm{KCl}, 2 \mathrm{CaCl}_{2}, 1 \mathrm{MgCl}_{2}, 10 \mathrm{HEPES}$, 


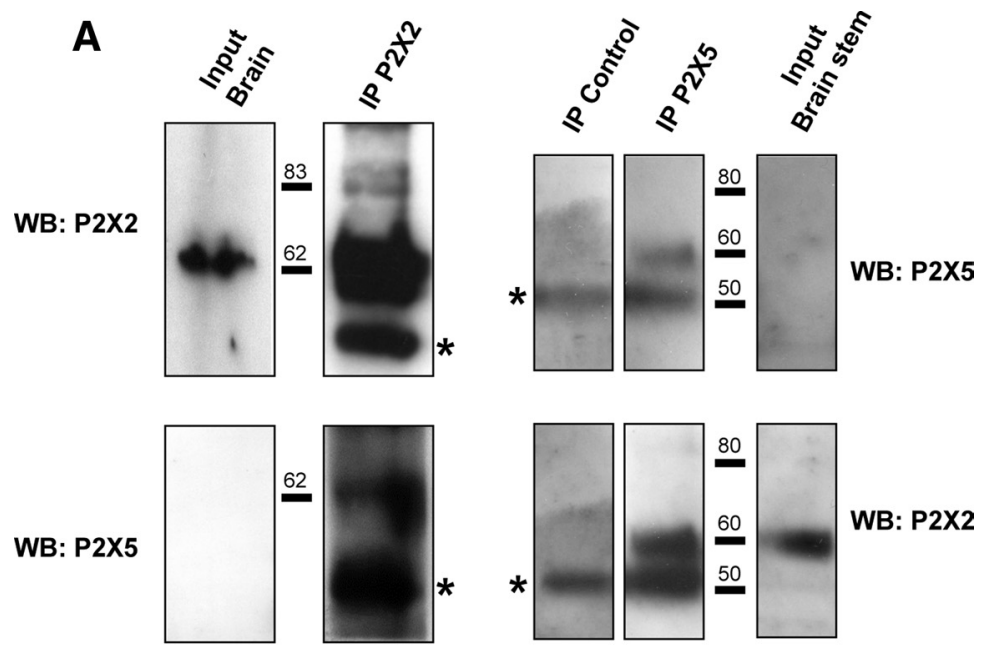

B
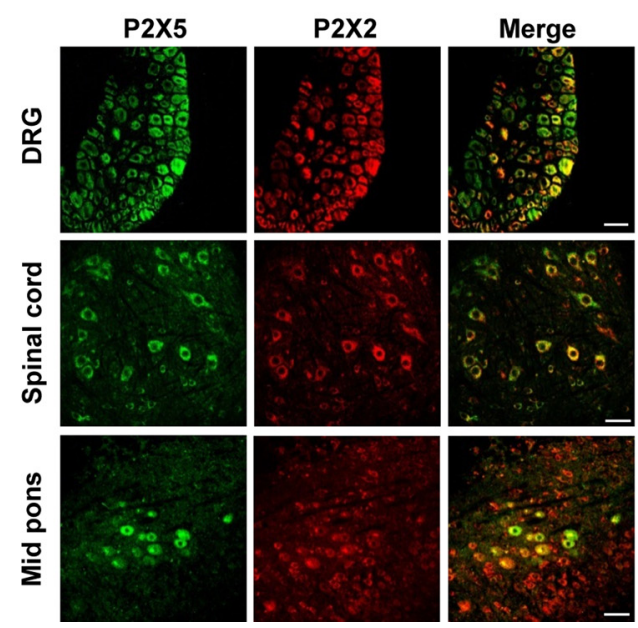

Figure 2. $P 2 X 5$ and $P 2 X 2$ subunits interact in neuronal tissues. $A$, Physical interactions of $P 2 X 2$ and $P 2 X 5$ subunits in brain tissues. P2X2 or P2X5 subunits were immunoprecipitated from mouse brain membrane and different subunits detected with specific antibodies. Left panel represents immunoprecipitation from total brain membrane proteins, right panel from brainstem. Note that P2X5 is not detectable from the total protein extract. Blots are representative of three independent experiments. Asterisks indicate the antibody heavy chains. $B$, Coimmunolocalization of P2X2 and P2X5 subunits in peripheral and central neurons. Representative images of immunohistochemistry performed on slices from DRG, spinal cord, or mid pons. P2X2 and P2X5 are stained in red and green, respectively. Note that in each structure only a subset of neurons coexpresses both subunits. Scale bar, $40 \mu \mathrm{m}$.

subunits could be rescued by coexpression with wild-type subunits, likely within a heteromeric channel (Chaumont et al., 2004). We used this property in the present study to screen for any rat subunits potentially interacting with $\mathrm{P} 2 \mathrm{X} 2$. Our results indicated that in addition to $\mathrm{P} 2 \mathrm{X} 2$ and $\mathrm{P} 2 \mathrm{X} 3$, only the $\mathrm{P} 2 \mathrm{X} 5$ subunit was able to rescue membrane expression of the P2X2-K366A trafficking mutant (Fig. 1A). We next performed the converse experiment to investigate subunits that might interact with rat P2X5. As shown in Figure $1 B$, membrane expression of the P2X5-K372A trafficking mutant was rescued upon coexpression with $\mathrm{P} 2 \mathrm{X} 1, \mathrm{P} 2 \mathrm{X} 2, \mathrm{P} 2 \mathrm{X} 4$, and P2X5 subunits. In this case, because the signal of P2X $5-\mathrm{K} 372 \mathrm{~A}$ at the plasma membrane was very low (data not shown), the level of rescue of P2X5mutated subunits appeared substantially higher than observed for P2X2-K366A. According to our interpretation that membrane expression of trafficking-deficient subunits can be rescued by specific interaction with any wild-type subunit, these results suggest that P2X5 subunits can specifically assemble with $\mathrm{P} 2 \mathrm{X} 1, \mathrm{P} 2 \mathrm{X} 2$, $\mathrm{P} 2 \mathrm{X} 4$, and $\mathrm{P} 2 \mathrm{X} 5$, establishing $\mathrm{P} 2 \mathrm{X} 2$ and $\mathrm{P} 2 \mathrm{X} 4$ as new potential partners of P2X5. $\mathrm{P} 2 \mathrm{X} 4$ interactions with P2X5 were not investigated further in this study.

To confirm the interaction between P2X2 and P2X5 subunits, we performed immunoprecipitation after biotinylation of membrane proteins in living cells. HEK cells were transfected with P2X5 carrying a HA tag either alone or in combination with $\mathrm{P} 2 \mathrm{X} 2$ subunits carrying a C-terminal GFP. After $48 \mathrm{~h}$, living cells were biotinylated and P2X5 subunits were immunoprecipitated using an anti-HA antibody. The results

and $13 \mathrm{D}$-glucose, and the intracellular pipette solution contained in mм: $145 \mathrm{NaCl}, 10$ HEPES, and 10 EGTA (pH adjusted to 7.3 with $\mathrm{NaOH}$, $\sim 320 \mathrm{mOsm} / \mathrm{L}$ ). Data were low-pass filtered at $2 \mathrm{kHz}$ and digitized at 5 kHz. Agonists were applied using an RSC 200 system (Biological Science Instruments). Test concentrations of ATP and BzATP (100 and $300 \mu \mathrm{M}$, respectively) were applied for $2 \mathrm{~s}$ at $2 \mathrm{~min}$ intervals, alternating which agonist was applied first.

For NMDG permeability experiments, the extracellular solution contained in mM either: $135 \mathrm{NaCl}, 20$ TEACl, $2 \mathrm{CaCl}_{2}, 1 \mathrm{MgCl}_{2}$, and 10 HEPES ( $\mathrm{pH}$ adjusted to 7.3 with $\mathrm{KOH}, \sim 320 \mathrm{mOsm}$ ) or $160 \mathrm{NMDG}, 0.1$ $\mathrm{CaCl}_{2}, 1 \mathrm{MgCl}_{2}$, and 10 HEPES (pH adjusted to 7.3 with $\mathrm{HCl}$ ). Borosilicate glass pipettes had a typical resistance of $1.5-2.5 \mathrm{M} \Omega$ when filled with an internal solution containing in mM: $140 \mathrm{CsCl}, 10$ EGTA, 10 HEPES, 3 Mg-ATP, 0.6 GTPNa, and $3 \mathrm{CaCl}_{2}$ (pH adjusted to 7.3 with $\mathrm{KOH}, \sim 315$ mOsm). Junction potentials in NMDG solutions $(\sim 10 \mathrm{mV})$ were not compensated. Drugs were applied by a homemade gravity-driven perfusion system.

\section{Results}

Determination of $\mathrm{P} 2 \mathrm{X}$ subunit interactions at the plasma membrane

Using a cellular ELISA assay, we previously demonstrated that membrane expression of trafficking-deficient mutants of rat P2X shown in Figure $1 C$ indicate that $\mathrm{P} 2 \mathrm{X} 5$ coimmunoprecipitates with P2X2 subunits and that all the subunits are biotinylated, establishing that P2X5 and P2X2 subunits interact at the plasma membrane. Identical results were obtained with fulllength human P2X2 and P2X5 subunits (Fig. $1 D$ ). However, as previously described (Kotnis et al., 2010), we observed that the human P2X 5 subunit with exon 10 deleted (hP2X5- $\Delta \mathrm{X}$, a form predominantly expressed in humans) was not expressed at the plasma membrane and triggered a strong reduction of cell surface expression of P2X2 upon coexpression (data not shown), suggesting a dominant-negative effect.

The above results were further confirmed by immunocytochemistry. Rat P2X $5^{\mathrm{Myc}}$ was transfected into HEK cells either alone or with P2X2-GFP cDNA. Immunodetection of P2X5 $5^{\mathrm{Myc}}$ was performed on living cells by incubation of the anti-Myc antibody in the culture medium, while $\mathrm{P} 2 \mathrm{X} 2$ subunits were detected through GFP fluorescence. Figure $1 E$ shows that P2X $5^{\text {Myc }}$ immunostaining was clearly localized to the plasma membrane and closely overlapped with the GFP signals. Altogether, our results demonstrate that P2X5 subunits interact at the plasma membrane with P2X2. These results provide evidence for the existence 
of interactions between these subunits, but do not provide information as to whether they occur directly within a heteromeric channel, or indirectly between two homomeric receptors.

\section{Association of P2X5 and P2X2 subunits in brain tissues}

In situ hybridization data indicates sparse expression of P2X5 subunits within the nervous system, mostly restricted to the DRG, spinal cord, and mid brain nuclei (Collo et al., 1996). We thus performed coimmunoprecipitation of P2X2 and P2X5 from total mouse brain and brainstem membrane protein extracts, respectively. As shown in Figure $2 \mathrm{~A}$, both anti-P2X 5 and anti-P2X2 antibodies coimmunoprecipitated the alternate subunit. P2X5 protein could not be detected from the total protein extracts, further supporting a low level of expression of this subunit in the CNS. We next analyzed the colocalization of the two subunits by immunohistochemistry. Sections from mouse DRGs, spinal cord, and mid pons were labeled with anti-P2X5 and anti$\mathrm{P} 2 \mathrm{X} 2$ antibodies. In these three regions, clear cellular colocalizations of the two proteins were observed (Fig. 2B). Aside from DRG neurons that showed strong P2X5 immunostaining, P2X5 expression in the spinal cord was restricted to a subpopulation of neurons in lamina VII, and to the trigeminal mesencephalic nucleus in the pons. In all three regions, only a subset of neurons coexpressed both subunits, supporting the specificity of the staining.

\section{P2X subunit interaction allows bioluminescent resonance energy transfer}

As stated above, interactions of recombinant P2X 5 and P2X2 subunits may occur within a heteromeric channel, or through indirect interactions of homomeric receptors. To answer this question, we used BRET to evaluate whether the distance between P2X5 and P2X2 subunits is compatible with the formation of a heteromeric receptor. P2X2 and P2X5 subunits were fused to either Renillia luciferase (Rluc) or enhanced yellow fluorescent protein (YFP) through their C termini. BRET titration curves were performed in living cells for different combinations of subunits: homomeric P2X5 and P2X2 receptors, or in combination of P2X5:P2X2 (Fig. 3). The G-proteincoupled receptor PAR1-YFP and ATP-gated channel P2X4YFP were used to assess the specificity of BRET signals (Ayoub et al., 2007). As shown in Figure $3 A$, when P2X5-Rluc was coexpressed with P2X5-YFP, or P2X2-YFP, a specific BRET signal was observed, characterized by a hyperbolic increase of the signal. In converse experiments, specific BRET signals were only observed between P2X2-Rluc and P2X2-YFP or $\mathrm{P} 2 \mathrm{X} 5$-YFP but not between P2X2-Rluc and P2X4-YFP or mean \pm SEM of triplicate.
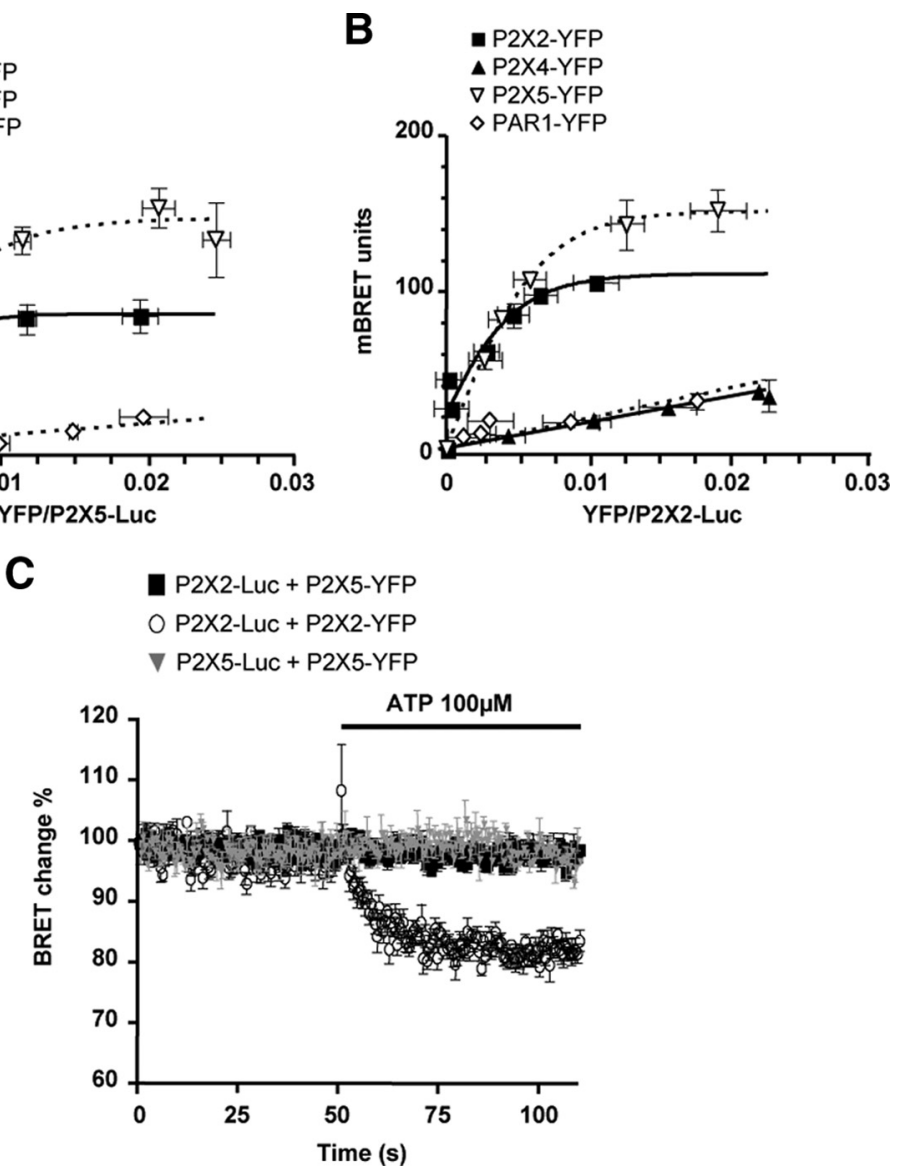

Figure 3. $P 2 X 5$ subunits are in close spatial proximity to $P 2 X 2$ subunits. $A, B R E T$ titration curves using $P 2 X 5$-Luc as the energy subunits, but not P2X4 and PAR-1. Data are expressed as mean \pm SEM of at least $N=3$ experiments. $C$, Cytosolic domains of a $2 X 2$ receptors undergo differential conformational changes after ATP stimulation. Dynamic BRET signals were reYFP tag on their ( terminus tail, alone or in combination. ATP stimulation induced a diminution of BRET signal between P2X2 subunits, which is not observed for P2X2/5 and P2X5 receptors. Representative experiment reproduced three times. Data are

PAR1-YFP (Fig. 3B). These results support the existence of heteromeric $\mathrm{P} 2 \mathrm{X} 2 / 5$ receptors.

The carboxyl cytosolic regions of P2X2 undergo conformational rearrangement that can be evidenced using dynamic measurement of fluorescence energy transfer (FRET) between individual subunits (Fisher et al., 2004). We investigated whether such conformational movements also occurred in $\mathrm{P} 2 \mathrm{X} 2 / 5$ receptors. The dynamics of BRET signals after stimulation with $100 \mu \mathrm{M}$ ATP were measured in living HEK cells expressing different combinations of $\mathrm{P} 2 \mathrm{X}$ subunits. As shown in Figure $3 C$, in cells expressing homomeric P2X2 subunits (P2X2-Rluc and P2X2-YFP), stimulation with ATP induced a $20 \%$ reduction of the BRET signal, with an estimated time constant of $5 \mathrm{~s}$. In cells expressing homomeric $\mathrm{P} 2 \mathrm{X} 5$ receptors or P2X2/5, ATP stimulation did not induce any change in the BRET signal. These results show that ATP-induced conformational movements of the cytosolic tails of P2X2 subunits are either impaired or undetectable when coexpressed with P2X5. Alternatively, these conformational changes might be specific to homomeric $\mathrm{P} 2 \mathrm{X} 2$ receptors. 
A
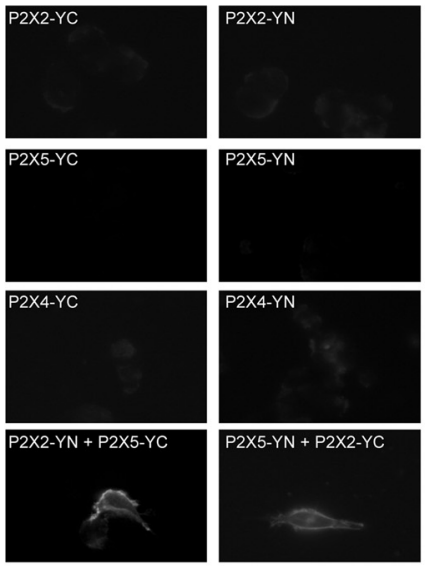

BRET

$P 2 X-L u C+P 2 X-(Y N+Y C)$

B
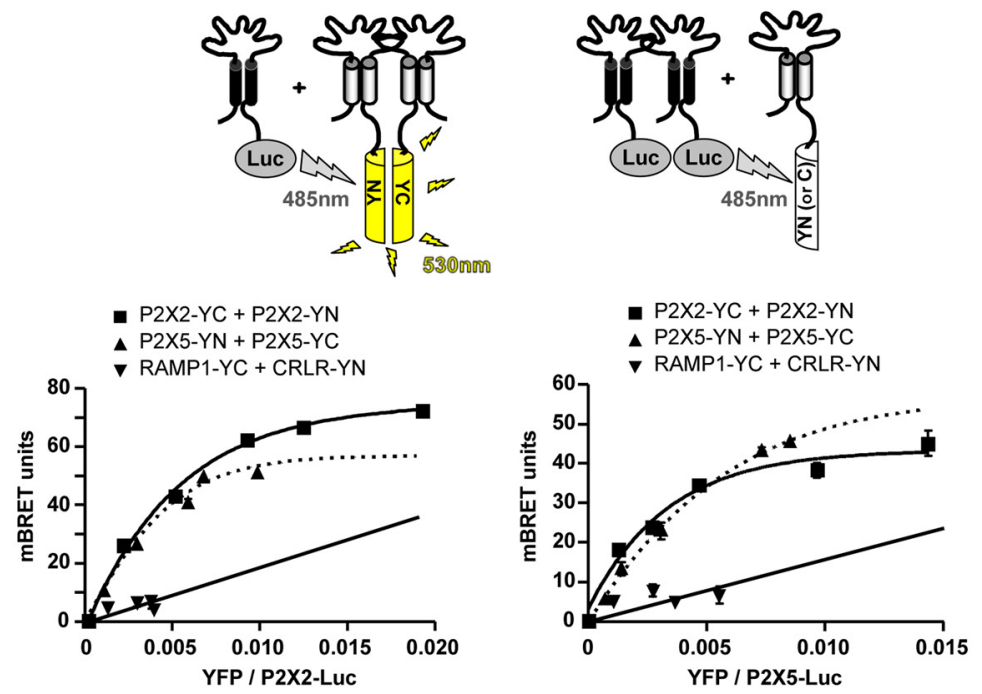

Figure 4. Stoichiometry of P2X2 and P2X5 interactions as assessed by BiFC and BRET/BiFC. $A$, Bimolecular fluorescence complementation between P2X subunits. P2X subunits fused to either the amino or carboxyl half of YFP (YN or YC) were transfected alone or in combination in HEK cells. Recomplemented fluorescence was observed by microscopy. BiFC was observed between homomeric P2X2, P2X4, and $P 2 X 5$ subunits, as well as between heteromeric $P 2 X 2$ and $P 2 X 5$ subunits, but not between $P 2 X 2$ and $P 2 X 4$ subunits. Scale bar, $10 \mu \mathrm{m}$. $\boldsymbol{B}$, Combination of BRET and BiFC reveals the stoichiometry of the heteromeric P2X2/P2X5 assembly. Top, Diagram illustrating the approach. BRET is only observed between one P2X2-Luc subunit and any other combinations of two P2X-hemi-YFP subunits. BRET titration curves between P2X2-Luc (left) or P2X5-Luc (right) cotransfected with P2X2, P2X5, RAMP1, and CRL fused to hemi-YFP. Specific BRET signals were observed between $P 2 X 2$ and P2X5 subunits for each experimental condition, demonstrating the existence of heteromeric receptors with two different stoichiometries. Data are expressed as mean \pm SEM of at least $N=3$ experiments.

Analysis of $\mathrm{P} 2 \mathrm{X} 2 / 5$ receptor stoichiometry by combined BRET and bimolecular fluorescence complementation

We next sought to determine the stoichiometry of the P2X2/5 complex in living cells by combining BiFC and BRET approaches. We first analyzed BiFC in homomeric P2X subunit assemblies. $\mathrm{P} 2 \mathrm{X} 2, \mathrm{P} 2 \mathrm{X} 4$, and $\mathrm{P} 2 \mathrm{X} 5$ fused through their $\mathrm{C}$ termini to either the amino or carboxyl half of YFP (YN and YC, respectively) were transfected in HEK cells, either alone or in combination. As shown in Figure $4 A$, complementation of the YFP fluorescence was observed for the three homomeric combinations of subunits tested. Similarly, BiFC was also observed between P2X2 and P2X5 subunits, but not P2X4 and P2X2 (Fig. 4A). We next probed the subunit stoichiometry of $\mathrm{P} 2 \mathrm{X} 2 / 5$ receptors by combining $\mathrm{BiFC}$ and BRET techniques. Cells were cotransfected with [P2X2-Rluc + $\mathrm{P} 2 \mathrm{X} 2-\mathrm{YN}+\mathrm{P} 2 \mathrm{X} 2-\mathrm{YC}]$, [P2X2-Rluc + P2X5-YN + P2X5-YC], $[\mathrm{P} 2 \mathrm{X} 5-\mathrm{Rluc}+\mathrm{P} 2 \mathrm{X} 5-\mathrm{YN}+\mathrm{P} 2 \mathrm{X} 5-\mathrm{YC}]$, or [P2X5-Rluc + P2X2-
$\mathrm{YN}+\mathrm{P} 2 \mathrm{X} 2-\mathrm{YC}]$, and BRET titration curves generated. As shown in Figure 4, $B$ and $C$, specific BRET signals were observed for every combination of subunit tested, thus establishing that heteromeric $\mathrm{P} 2 \mathrm{X} 2 / 5$ display two different stoichiometries in living cells.

\section{Biochemical characterization of P2X2 and $\mathrm{P} 2 \mathrm{X} 5$ interactions}

The above results support that $\mathrm{P} 2 \mathrm{X} 2$ and $\mathrm{P} 2 \mathrm{X} 5$ subunits associate in a heteromeric receptor complex. However, energy transfer can result from higher order oligomerization states of membrane receptors (Khakh et al., 2005; Guo et al., 2008). Furthermore, energy transfer experiments do not give an indication as to whether these interactions occur at the plasma membrane or in intracellular compartments. To resolve these issues, biochemical characterization of the P2X2/P2X5 subunit complex was carried out. First, we analyzed the native oligomeric organization of $\mathrm{P} 2 \mathrm{X} 2$ and $\mathrm{P} 2 \mathrm{X} 5$ subunits using the PFO/PAGE method (Ramjeesingh et al., 1999). We established that $0.5 \%$ PFO efficiently solubilized P2X2 and P2X5 receptor complexes into two main forms corresponding to a dimeric and trimeric assembly of subunits, and a minor form corresponding to the monomeric subunit (data not shown).

We next analyzed the quaternary structure of the $\mathrm{P} 2 \mathrm{X} 2 / \mathrm{P} 2 \mathrm{X} 5$ complex. Because the molecular weights of P2X2 and P2X5 subunits are similar, we used P2X subunits fused to the YC3.1 cameleon protein (Cam) to obtain good molecular weight discrimination between homomeric and heteromeric receptors. PFO/PAGE analysis shows that the presence of Cam as a fusion partner did not alter the trimeric architecture of the homomeric P2X2 or P2X5 channel complex (Fig. 5A). We next analyzed the homomeric receptor complex made by the association of Cam- and Myc-tagged subunits (P2X2-Cam:P2X2-Myc and P2X5-Cam:P2X5-Myc). After solubilization and $\mathrm{PFO} / \mathrm{PAGE}$, proteins were revealed using an anti-Myc antibody. For both receptors, in addition to the trimeric association of Myc subunits, a single higher molecular weight form was clearly detected (Fig. 5A, $B$, indicated by an asterisk), which can only correspond to a trimeric receptor made by the association of two Myc-tagged subunits and one Cam tagged. The presence of a single Cam subunit in the trimeric complex is likely due to slower maturation of Cam tagged proteins. Finally, P2X2 and P2X5 heteromeric subunit oligomerization was analyzed. In both conditions (P2X5-Myc:P2X2-Cam or P2X2-Myc:P2X5-Cam), a single high molecular weight form, larger than the homotrimeric Myc subunit oligomer, was detected. These results demonstrate that (1) P2X2 and P2X5 subunits associate within a heterotrimeric receptor complex, and (2) this receptor exists with two different subunit stoichiometries. 
We next asked whether both forms of the heteromeric $\mathrm{P} 2 \mathrm{X} 2 / 5$ receptor are present at the plasma membrane. Plasma membrane P2X receptors were crosslinked in living cells using BS3, a membrane impermeable cross-linker with an $11.4 \AA$ spacer arm, and separated by SDS/ PAGE. As shown in Figure 5B, both homotrimeric P2X-Cam and P2X-Myc receptors were efficiently cross-linked at the plasma membrane. However, in the case of $\mathrm{P} 2 \mathrm{X}$-Cam receptors, monomeric subunits were still detected, further supporting that P2X-Cam subunits do not reach the plasma membrane as efficiently as P2X-Myc. Analysis of cross-linked P2X-Cam/P2X-Myc receptors revealed the presence of a single high molecular weight band above the trimeric form of $\mathrm{P} 2 \mathrm{X}-\mathrm{Myc}$ receptors, which corresponds to a trimeric receptor made by the association of two P2X-Myc subunits and one $\mathrm{P} 2 \mathrm{X}$-Cam subunit. This was true for all combinations of subunits tested (P2X2-Myc + P2X2-Cam, P2X5-Myc + P2X5-Cam, P2X2$\mathrm{Myc}+\mathrm{P} 2 \mathrm{X} 5-\mathrm{Cam}, \mathrm{P} 2 \mathrm{X} 5-\mathrm{Myc}+\mathrm{P} 2 \mathrm{X} 2-$ Cam). These results establish that the two stoichiometries of $\mathrm{P} 2 \mathrm{X} 2 / 5$ receptors are both expressed at the plasma membrane.

\section{P2X2/5 receptors display specific \\ functional properties}

The functional properties of $\mathrm{P} 2 \mathrm{X} 2 / 5$ receptors were analyzed in mRNA-injected Xenopus oocytes. To minimize the presence of homomeric $\mathrm{P} 2 \mathrm{X} 2$ receptors, $\mathrm{P} 2 \mathrm{X} 2$ and P2X5 mRNA were injected at a 1:3 ratio, respectively. The $\mathrm{P} 2 \mathrm{X} 2 / 5$ receptor pharmacological profile was established and compared with that of $\mathrm{P} 2 \mathrm{X} 2$ receptors. The results are summarized in Table 1 , and show that the apparent affinities of the P2X2/5 receptor for ATP, BzATP, and $\mathrm{ATP} \gamma \mathrm{S}$ are somewhat lower than for P2X2 receptors. While ATP and ATP $\gamma \mathrm{S}$ were full agonists for the two receptors, BzATP efficacy was significantly lower at P2X2/5 receptors. Furthermore, TNP-ATP inhibited $\mathrm{P} 2 \mathrm{X} 2 / 5$ to a greater extent than $\mathrm{P} 2 \mathrm{X} 2$ receptors, while $\alpha \beta$ meATP was unable to activate either receptor, even at $300 \mu \mathrm{M}$.

Coexpression of $\mathrm{P} 2 \mathrm{X} 2$ and $\mathrm{P} 2 \mathrm{X} 5$ subunits can lead to a mixture of four different homomeric and heteromeric receptors, making it difficult to precisely characterize the pharmacological profile of heteromeric $\mathrm{P} 2 \mathrm{X} 2 / 5$ receptors. We previously described that, within a heteromeric receptor, function of the $\mathrm{P} 2 \mathrm{X} 2-\mathrm{K} 366 \mathrm{~A}$ mutant can be rescued by coexpression with wild-type $\mathrm{P} 2 \mathrm{X} 3$ subunits (Chaumont et al., 2004). We sought to determine whether a similar rescue could be obtained upon coexpression with P2X5 subunits. As shown in Table 2, coexpression of P2X5 with P2X2-K366A in

\section{A PFO-PAGE}

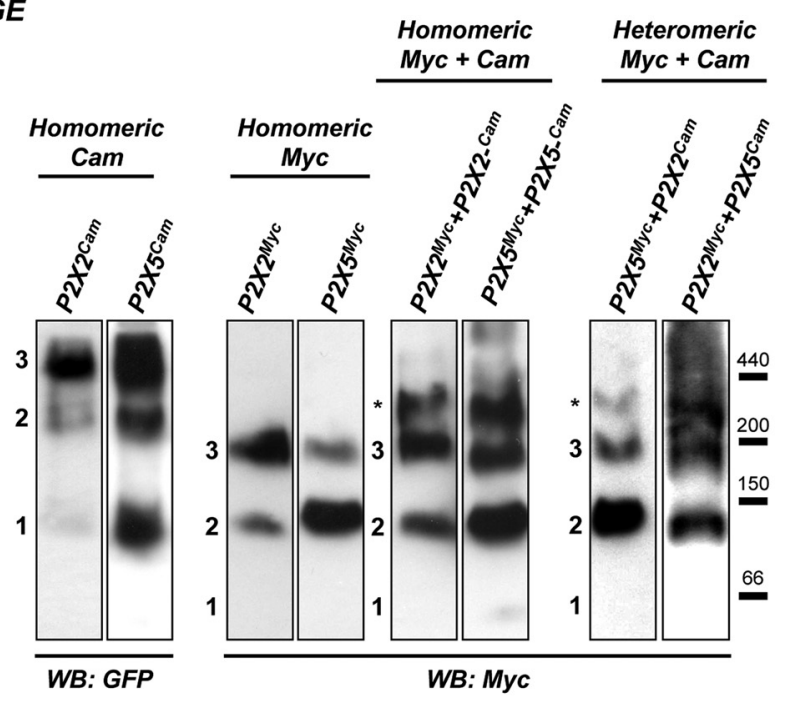

\section{B BS3 cross-linking}
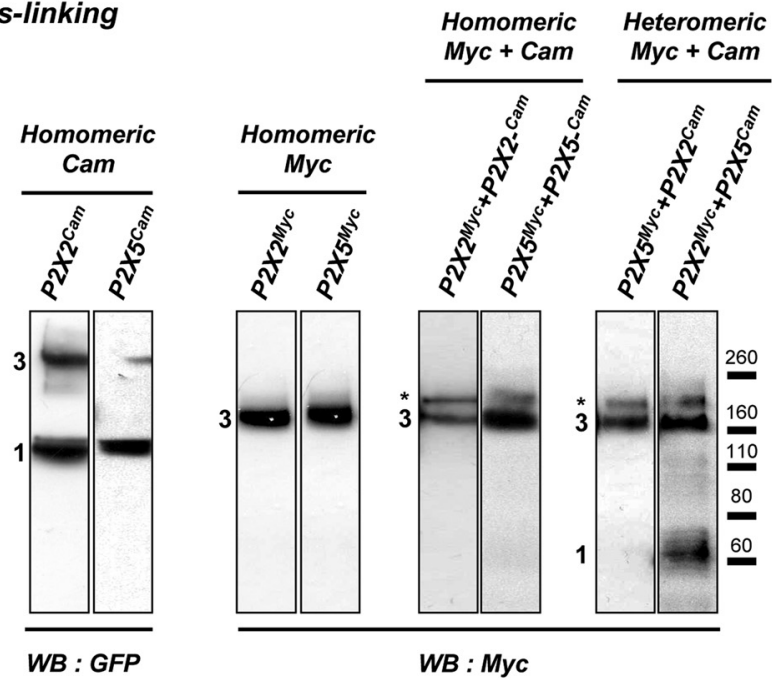

Figure 5. Biochemical analysis of $P 2 \times 2 / 5$ subunit assembly. $A$, Analysis of the $P 2 \times 2 / 5$ subunit complex in native conditions using PF0-PAGE. HEK cells were transfected with P2X subunits with either a Myc tag or the Cam protein fused to their C terminus. Homomeric P2X2 and P2X5 receptors fused to Myc or Cam are resolved as monomers, dimers, and trimers (indicated by numbers). When Myc and Cam fused P2X subunits are coexpressed, an additional high molecular weight form of the complex (indicated by an asterisk) is detected, which corresponds to a stoichiometry of two Myc subunits for one Cam subunit. Molecular weight markers apoferritin (440 kDa), $\beta$-amylase (200 kDa), alcohol dehydrogenase (150 kDa), and bovine serum albumin (66 kDa) were detected by Ponceau red staining before membrane blocking. $B, P 2 \times 2 / 5$ receptors are present at the plasma membrane with two different stoichiometries. Stoichiometry of $\mathrm{P} 2 \mathrm{X}$ receptors at the plasma membrane was analyzed after living cell surface protein crosslinking with the membrane impermeable cross-linker BS3. Cross-linked P2X subunits were analyzed by SDS/PAGE. Homomeric Myc-tagged receptors are resolved as a single band corresponding to the molecular weight of a trimer, while Cam-tagged subunits migrate as monomers and trimers. When Myc- and Cam-fused P2X subunits are coexpressed, an additional high molecular weight form of the cross-linked receptor (indicated by an asterisk) is detected, corresponding to a stoichiometry of one P2X-Cam subunit and two P2X-Myc subunits. All data are representative of $N>3$ independent experiments.
HEK cells at a ratio of 1:1 yielded currents that were not significantly larger than when either construct were expressed alone. Shifting the ratio of plasmids toward either P2X2K366A or P2X5 resulted in smaller currents (data not shown). Conversely, coexpression of $\mathrm{P} 2 \mathrm{X} 5-\mathrm{K} 372 \mathrm{~A}$ with $\mathrm{P} 2 \mathrm{X} 2$ resulted in ATP- and BzATP-evoked currents, with densities similar to cells coexpressing P2X 2 and $\mathrm{P} 2 \mathrm{X} 5$ subunits. These results suggest that heteromeric $(\mathrm{P} 2 \mathrm{X} 2)_{2} / \mathrm{P} 2 \mathrm{X} 5-\mathrm{K} 372 \mathrm{~A}$ are functional and display a lower sensitivity to BzATP. However, under these experimental conditions, the presence of functional ho- 
Table 1. Pharmacological properties of $\mathrm{P} 2 \mathrm{X} 2, \mathrm{P} 2 \mathrm{X} 2 / 5$, and $\mathrm{P} 2 \mathrm{X} 5$ receptors expressed in Xenopus 0ocytes

\begin{tabular}{|c|c|c|c|c|c|c|c|c|}
\hline & \multicolumn{2}{|l|}{ ATP } & \multicolumn{2}{|l|}{ BzATP } & \multicolumn{2}{|l|}{ ATP $\gamma S$} & \multicolumn{2}{|l|}{ TNP-ATP } \\
\hline & $\mathrm{EC} 50, \mu \mathrm{M}$ & $I / I_{\mathrm{P} 2 \times 2}(100 \mu \mathrm{M}) \%$ & $\mathrm{E}(5, \mu \mathrm{M}$ & $I_{\text {BzATP }} / I_{\text {ATP }},{ }^{a} \%$ & $\mathrm{E}(50, \mu \mathrm{M}$ & $I_{\text {ATP } \gamma S} / I_{\text {ATP }},{ }^{b} \%$ & $1 \mu \mathrm{M}_{,}{ }^{\mathrm{C}} \%$ & $10 \mu \mathrm{M}, \%$ \\
\hline $\mathrm{P} 2 \times 2$ & $5.3 \pm 0.9(n=5)$ & $100 \pm 0.06(n=5)$ & $28 \pm 0.4(n=5)$ & $60.6 \pm 6.9(n=5)$ & $5.9 \pm 0.2(n=6)$ & $94.4 \pm 4.1(n=6)$ & $96 \pm 0.9(n=3)$ & $46.1 \pm 6.4(n=11)$ \\
\hline $\mathrm{P} 2 \times 2 / 5$ & $12.6 \pm 0.4^{* *}(n=13)$ & $90.9 \pm 3.9(n=13)$ & $82 \pm 0.9^{* * *}(n=6)$ & $14.1 \pm 3.1^{* * *}(n=6)$ & $22.3 \pm 0.1^{* * *}(n=8)$ & $113 \pm 4.5(n=8)$ & $85.9 \pm 3.14(n=11)$ & $20.8 \pm 2.5^{* *}(n=11)$ \\
\hline$P 2 \times 5$ & $18.7 \pm 2^{* *}(n=7)$ & $6.7 \pm 2.7^{* * *}(n=7)$ & N.D. & N.D. & N.D. & N.D. & N.D. & N.D. \\
\hline
\end{tabular}

In the case of P2X2/5 expression, $\mathrm{P} 2 \mathrm{X} 5$ and $\mathrm{P} 2 \mathrm{X} 2 \mathrm{mRNAs}$ were mixed at a 3:1 ratio to minimize the presence of homomeric $\mathrm{P} 2 \mathrm{X} 2$ receptors. Consequently, for homomeric $\mathrm{P} 2 \mathrm{X} 2$ expression, $\mathrm{mRNA}$ was diluted at the same ratio with water. $\mathrm{P} 2 \mathrm{X} 5$ mRNA was not diluted for homomeric P2X5 expression. ${ }^{* *} p<0.01,{ }^{* * *} p<0.005$, unpaired Student's $t$ test.

${ }_{300} \mu \mathrm{m}$ BzATP, $100 \mu \mathrm{M}$ ATP.

${ }^{b} 100 \mu \mathrm{M}$ ATP $\gamma \mathrm{S}, 30 \mu \mathrm{M}$ ATP.

'P2X2 was activated with $10 \mu \mathrm{M}$ ATP; P2X2/5 was activated with $30 \mu \mathrm{M}$ ATP. Percentage of residual current in the presence of TNP-ATP.

Table 2. Analysis of $\mathrm{P} 2 \mathrm{X2} / 5$ receptors containing trafficking mutant subunits $\mathrm{HEK}$ cells transfected with $\mathrm{P} 2 \mathrm{X2}$, P2X2-K366A, P2X5, and P2X5-K372A subunits or the different combination

\begin{tabular}{lccllr}
\hline & $I_{\text {ATP }}, \mathrm{PA} / \mathrm{pF}$ & $I / I_{\text {P2X2 }}, \%$ & $I_{\text {BZATP }}, \mathrm{PA} / \mathrm{pF}$ & $I_{\text {BZATP }} / I_{\text {ATP }}$ & \multicolumn{1}{c}{$n$} \\
\hline P2X2 & $-845 \pm 76$ & 100 & $-416 \pm 76$ & $0.48 \pm 0.04$ & 18 \\
P2X5 & $-2.1 \pm 0.9$ & 0.27 & - & - & 16 \\
P2X2-K366A & $-1.5 \pm 0.5$ & 0.15 & - & - & 6 \\
P2X2-K366A + P2X5 & $-10.2 \pm 1.6$ & 1.1 & $-2.8 \pm 0.4$ & $0.35 \pm 0.04^{*}$ & 23 \\
P2X2 + P2X5 & $-390 \pm 75$ & 45.5 & $-112 \pm 29$ & $0.26 \pm 0.02^{* *}$ & 14 \\
P2X2 + P2X5-K372A & $-446 \pm 123$ & 51.6 & $-104 \pm 25$ & $0.30 \pm 0.03^{*}$ & 9
\end{tabular}

Currents were evoked by BzATP $(300 \mu \mathrm{M})$ and ATP $(100 \mu \mathrm{M})$. No response to BzATP was detected for P2X5 or P2X2-K366A. I BzATP $_{1} / I_{\text {ATP }}$ was calculated using the averaged responses to each agonist from individual cells. Results are shown as mean \pm SEM. ${ }^{*} p<0.05,{ }^{* *} p<0.01$ compared to P2X2, ANOVA followed by Tukey-Kramer multiple comparison test.

\section{A}

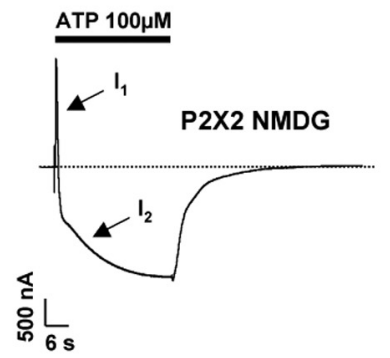

C

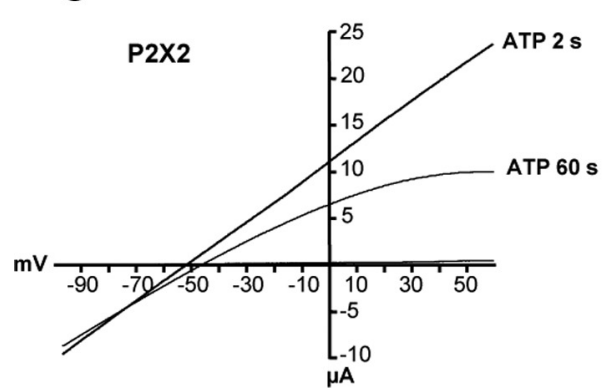

B

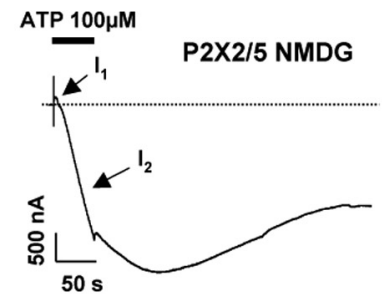

D

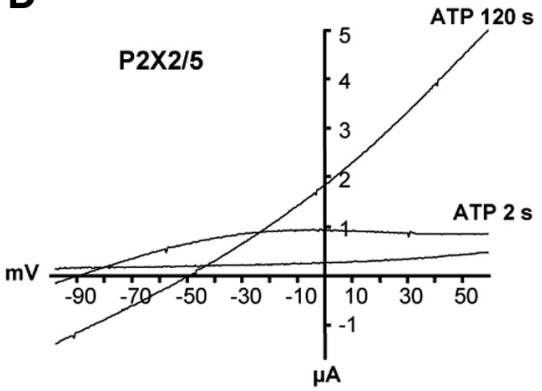

Figure 6. $P 2 X 2 / 5$ receptor stimulation evokes sustained NMDG conductance in Xenopus 0ocytes. Permeability dynamics of P2X2 (A) and P2X2/5 (B). Representative currents evoked by ATP (100 $\mu \mathrm{m})$ in Xenopus oocytes expressing P2X2 or P2X2/5 receptors recorded in NMDG external solution at a holding potential of $-60 \mathrm{mV}$. $I_{1}$ and $I_{2}$ correspond to channels permeant to small cations or NMDG ${ }^{+}$, respectively. Note the faster $I_{1}$ to $I_{2}$ transition for $P 2 X 2$ receptors compared with $P 2 X 2 / 5$, and the lack of reversibility of the inward $P 2 X 2 / 5$ conductance. C, D, Shift in the reversal potential of ATP-evoked currents in NMDG extracellular solution. Currents were measured during repeated voltage ramps protocol in the presence of $100 \mu \mathrm{m}$ ATP. Two seconds after ATP application, reversal potential of P2X2 current has already changed compared with that of P2X2/5. Note the difference in current rectification between the two types of channels.

momeric P2X2 receptors prevents any precise pharmacological characterization.

$\mathrm{P} 2 \mathrm{X} 2 / 5$ shows functional properties similar to $\mathrm{P} 2 \mathrm{X} 7$ receptors Upon prolonged ATP stimulation, a subset of $\mathrm{P} 2 \mathrm{X}$ receptors, including P2X2, can undergo a progressive change in permeabil- ity, and becoming permeant to large cations such as NMDG (Khakh et al., 1999; Virginio et al., 1999b). Until now, this property has never been investigated in heteromeric receptors. We thus compared the permeability dynamics of $\mathrm{P} 2 \mathrm{X} 2$ and $\mathrm{P} 2 \mathrm{X} 2 / 5$ receptors. In P2X2-expressing oocytes, stimulation with $100 \mu \mathrm{M}$ ATP in NMDG extracellular solution induced a rapid change in permeability characterized by a transient outward current $\left(I_{1}\right)$ followed by an inward current $\left(I_{2}\right)$, which rapidly reversed upon removal of ATP (Fig. 6A). This change in permeability was also observed as a rapid shift in the reversal potential of the currents. At $t=2 \mathrm{~s}, E_{\mathrm{rev}} 1=-72.4 \pm 1.3 \mathrm{mV}$ ( 24 cells, 5 experiments), at $t=60 \mathrm{~s}, E_{\mathrm{rev}} 2=-57.9 \pm 2.7 \mathrm{mV}$ ( 22 cells, 5 experiments $)$. In addition, strong inward rectification gradually developed during a 60 s ATP application (Fig. 6C). In oocytes expressing $\mathrm{P} 2 \mathrm{X} 2 / 5$ receptors, ATP-induced currents displayed a small initial outward current followed by a slowly developing large inward current (Fig. 6B). The shift in reversal potential was much slower and more pronounced than that observed for P2X2, at $t=2 \mathrm{~s}$, $E_{\mathrm{rev}} 1=-76.4 \pm 2.2 \mathrm{mV}$ ( 14 cells, 5 experiments), and at $t=120 \mathrm{~s}, E_{\mathrm{rev}} 2=$ $-39.9 \pm 2.3 \mathrm{mV}$ ( 14 cells, 5 experiments). The difference of $E_{\text {rev }} 2$ for P2X2 and P2X/ 5 -expressing oocytes is significantly different ( $p=0.0058$, Student's $t$ test). In contrast to what was observed for P2X2, P2X2/5 currents showed initial strong inward rectification, which progressively disappeared (Fig. 6D). The NMDG conductance persisted after washing off the agonist, eventually returning to baseline; often, the effect was not reversible and led to cell death. This late NMDG conductance was never observed in P2X2-expressing oocytes. Altogether, these results show that the change in permeability observed for $\mathrm{P} 2 \mathrm{X} 2 / 5$ is similar to that of $\mathrm{P} 2 \mathrm{X} 7$ receptors.

To further validate these observations, similar experiments were performed in HEK cells in which P2X2/5-evoked conductances were compared with those of P2X7. In HEK cells expressing P2X2/5 receptors, ATP induced a progressive shift in the reversal potential of the currents $\left(\Delta E_{\mathrm{rev}}=31.3 \pm 3.2 \mathrm{mV}\right.$, $n=9$ cells, two experiments at $60 \mathrm{~s})$, showing a time-dependent increase in NMDG permeability (Fig. 7A, left panel). This shift was more pronounced than in cells expressing $\mathrm{P} 2 \mathrm{X} 7$ receptors $\left(\Delta E_{\mathrm{rev}}=16.8 \pm 1.6 \mathrm{mV}, n=6\right.$ cells, 2 experiments $)$ or $\mathrm{P} 2 \mathrm{X} 2$ 
alone $\left(\Delta E_{\mathrm{rev}}=21.7 \pm 3 \mathrm{mV}, n=9\right.$ cells, 2 experiments) (Fig. $7 B, C$, respectively, left). $\Delta E_{\text {rev }}$ for $\mathrm{P} 2 \mathrm{X} 2 / 5$ - and $\mathrm{P} 2 \mathrm{X} 2$-expressing cells were significantly different. As observed in oocytes, a reduction of the outward rectification of $\mathrm{P} 2 \mathrm{X} 2 / 5$ current was observed $60 \mathrm{~s}$ after activation, leading to a quasi linear current/voltage curve, as for P2X7-evoked conductances.

We next compared P2X2/5- and P2X7-evoked conductances in NMDG solution. As shown in the right-hand panels of Figure 7, $A$ and $B$, activation of both receptors evoked currents that persisted after agonist washout. Furthermore, as previously reported (Jiang et al., 2005), this conductance quickly closed after change to an extracellular solution containing $\mathrm{NaCl}$. In contrast, the P2X2evoked NMDG conductance rapidly closed upon agonist washout (Fig. 7C, right). These data further support that $\mathrm{P} 2 \mathrm{X} 2 / 5$ and $\mathrm{P} 2 \mathrm{X} 7$ receptors, but not $\mathrm{P} 2 \mathrm{X} 2$, share similar functional properties.

Pore dilatation of $\mathrm{P} 2 \mathrm{X}$ receptors allows uptake of fluorescent dyes such as YoPro-1 (Virginio et al., 1999b). We compared the ability of $\mathrm{P} 2 \mathrm{X} 2$ and $\mathrm{P} 2 \mathrm{X} 2 / 5$ receptors to mediate Yo-Pro-1 uptake in HEK cells. In NMDG extracellular solution, $100 \mu \mathrm{M}$ ATP induced a timedependent Yo-Pro-1 uptake in cells expressing P2X2 or P2X2/5 (Fig. 8A,B). Compared with $\mathrm{P} 2 \mathrm{X} 2$-expressing cells, ATP-evoked Yo-Pro-1 uptake was greater in $\mathrm{P} 2 \mathrm{X} 2 / 5$ transfected cells (Fig. $8 C$ ) but had a significantly slower rate [for $100 \mu \mathrm{M}$ ATP, $\tau=1.981 \pm 0.153 \mathrm{~s}^{-1}\left(N=4 \mathrm{ex}^{-}\right.$ periments) and $\tau=3.052 \pm 0.133 \mathrm{~s}^{-1}$ ( $N=4$ experiments), for $\mathrm{P} 2 \mathrm{X} 2$ and $\mathrm{P} 2 \mathrm{X} 2 / 5$, respectively. $p=0.039$, Student's $t$ test]. In addition, there was a clear difference in the concentration-dependency of ATP-evoked Yo-Pro-1 uptake between $\mathrm{P} 2 \mathrm{X} 2$ and P2X2/5-expressing cells. ATP $(10 \mu \mathrm{M})$ induced fluorescence changes of 60 and $25 \%$ in cells expressing P2X2 and P2X2/5, respectively (Fig. $8 \mathrm{~B}$ ), while a subsequent stimulation with $100 \mu \mathrm{M}$ ATP induced an additional 30 and 75\% increase, respectively. Although P2X2/5-mediated Yo-Pro-1 uptake was slower, it evoked a significantly higher final level of fluorescence than was seen with P2X2 receptors (Fig. $8 C$ ). Interestingly, for both receptors, Yo-Pro-1 uptake was also observed in physiological solutions, albeit with lower efficacy (Fig. 8D). Similarly, in NaCl-based solution, ATP stimulation evoked EtBr uptake in HEK cells expressing P2X2, P2X2/5, or $\mathrm{P} 2 \mathrm{X} 7$ receptors (Fig. $8 E$ ). Compared with $\mathrm{P} 2 \mathrm{X} 2$, the kinetics of dye uptake was slower and almost linear for P2X2/5 and P2X7. After 2 $\mathrm{min}$, the increase of fluorescence induced by $\mathrm{P} 2 \mathrm{X} 2$ reached a plateau, whereas accumulation of dye still occurred $10 \mathrm{~min}$ after stimulation in cells expressing $\mathrm{P} 2 \mathrm{X} 2 / 5$ or P2X7. Altogether, these results show that dye uptake induced by $\mathrm{P} 2 \mathrm{X} 2 / 5$ receptors and $\mathrm{P} 2 \mathrm{X} 7$ display similar features.

One of the characteristics of the P2X7 receptor is its ability to induce membrane blebbing upon short ATP applications (Mack-

\section{A P2X2/5}

B $\quad \mathrm{P} 2 \mathrm{X7}$
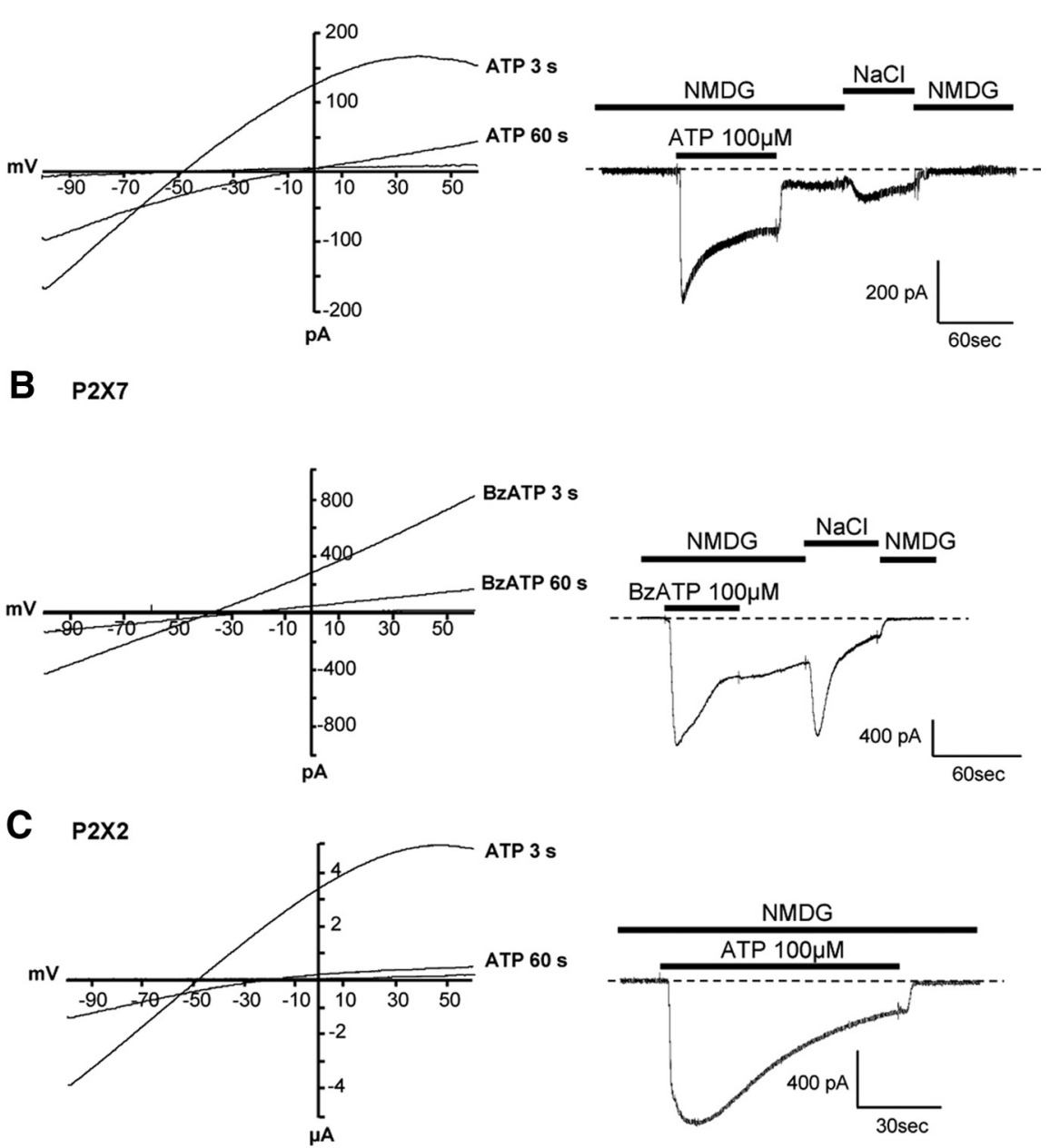

Figure 7. $P 2 X 2 / 5$ and P2X7 NMDG conductances display similar properties in HEK cells. Left, Shift in the reversal potential of ATP-evoked currents in NMDG extracellular solution in HEK cells expressing P2X2/5 (A), P2X7 (B), or P2X2 (C). Currents elicited by expressing P2X2/5 (A), P2X7 (B) or P2X2 (C). Holding potential $-60 \mathrm{mV}$. P2X2/5 and P2X7-expressing cells show a conductance that persists after agonist washout and can be fully blocked by extracellular $\mathrm{NaCl}$. Note that in P2X2-expressing cells, the NMDG conductance readily reverses upon agonist washout.

enzie et al., 2005; Morelli et al., 2003; Verhoef et al., 2003). We thus investigated whether $\mathrm{P} 2 \mathrm{X} 2 / 5$ activation could generate a similar phenotype. The membrane dynamics of HEK cells expressing P2X2/5-GFP were recorded using fluorescent time-lapse video-microscopy under normal culture conditions. Application of $100 \mu \mathrm{M}$ ATP triggered the appearance of membrane blebs in $50 \%$ of transfected cells (Fig. $9 A, B$ ). Interestingly, the overall membrane integrity was maintained throughout the 2 min recording period. In similar conditions, there was no difference in the number of blebbing cells between those expressing P2X2-GFP or P2X5-GFP, whereas P2X7-GFP activation induced membrane blebbing in $80 \%$ of transfected cells (Fig. $9 B$ ).

We next analyzed whether, as for P2X7 receptors, this membrane blebbing was associated with phosphatidylserine exposure (PS flip) and pseudoapoptosis (Mackenzie et al., 2005). HEK cells in physiological culture medium were stimulated with $100 \mu \mathrm{M}$ ATP for $5 \mathrm{~min}$, and PS flip was analyzed using annexin-V staining at different times following the stimulation (0,3, and $24 \mathrm{~h})$. Cells transfected with P2X2-YFP and P2X7-YFP were used as negative 
A

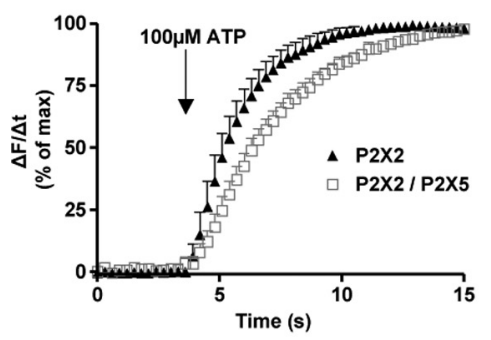

C

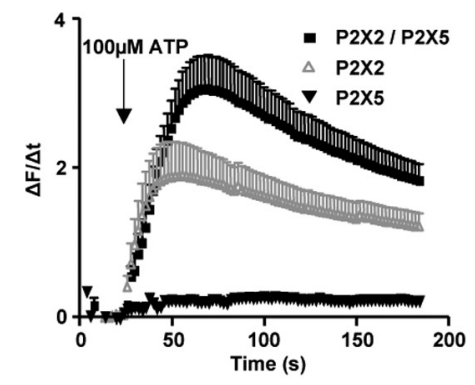

B

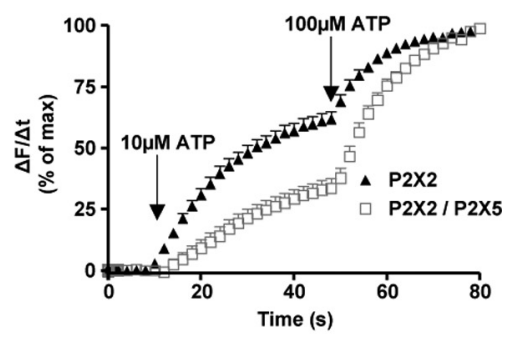

D

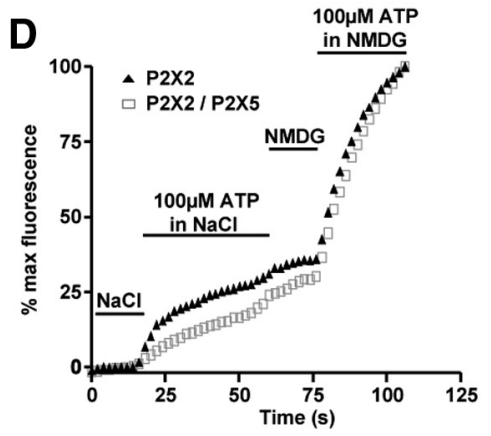

E

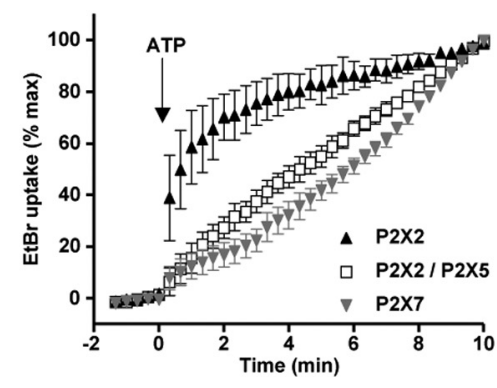

Figure 8. Activation of $\mathrm{P} 2 \mathrm{X} 2 / 5$ receptors induces dye uptake. $A, B$, ATP-evoked $\mathrm{Y}_{0}-\mathrm{Pro}-1$ uptake in HEK cells expressing $\mathrm{P} 2 \mathrm{X} 2$ or P2X2/5 receptors. Video-microscopy experiments were performed in NMDG extracellular solution. Individual cell fluorescence signals were differentiated and normalized to the maximal response. Data are mean \pm SEM of $n>10$ cells, $N=3-4$ experiments. Note that the kinetics of Y0-Pro-1 uptake are slower for P2X2/5 receptor compared with P2X2. C, P2X2/5 displays greater ATP-evoked Yo-Pro-1 uptake compared with P2X2. Experiments were performed as above, except that results were not normalized. Data are mean \pm SEM of $n>10$ cells, $N=4$ experiments. $D$, ATP-evoked Yo-Pro1 uptake occurs in physiological solution. Cells were stimulated as above, first in physiological solution (NaCl-based solution) and then in NMDG-based solution. In both conditions, ATP evoked Yo-Pro-1 uptake albeit with higher potency in NMDG solution. Data are mean of $n>10$ cells, $N=3$ experiments. SEM was omitted for clarity. $E$, Comparison of ethidium bromide uptake evoked by P2X2, P2X2/5, or P2X7 receptors stimulation. Cells were stimulated with $100 \mu \mathrm{m} \mathrm{ATP} \mathrm{(} 5 \mathrm{~mm}$ for P2X7) in NaCl-based solution. Results are mean \pm SEM, $n>30$ cells, $N=4$ experiments. Note that P2X2/5- and P2X7-evoked EtBr uptakes do not saturate.

and positive controls, respectively. In cells expressing $\mathrm{P} 2 \mathrm{X} 2 / 5-$ YFP, $>80 \%$ of YFP-positive cells also showed annexin-V staining at time 0 , and this proportion decreased to $<50 \% 3 \mathrm{~h}$ after the stimulation (Fig. 9C,D). After $24 \mathrm{~h}$, the number of annexin- $\mathrm{V}$ positive cells was not different from control. A similar trend was observed in cells expressing P2X7-YFP, while in P2X2-YFP transfected cells, annexin- $\mathrm{V}$ staining was not different from background. In all conditions, the number of YFP-positive cells remained unchanged, indicating that PS flip induced by short ATP applications did not engage cells in apoptotic cell death.

\section{Discussion}

Two main results have emerged from this work. First, we have established that the quaternary organization of $\mathrm{P} 2 \mathrm{X}$ subunits can be accurately defined using a combination of BRET and fluorescence complementation. Second, we have demonstrated that P2X5 and $\mathrm{P} 2 \mathrm{X} 2$ subunits associate in a new heteromeric receptor with two stoichiometries. We have provided evidence that this receptor is endogenously expressed within specific neuronal populations, and displays functional properties that were previously thought to be unique to the P2X7 receptor (Surprenant et al., 1996).

Our cell surface assay (Chaumont et al., 2004) allowed a preliminary screening of P2X subunits interacting at the plasma membrane. Indeed, this approach has accurately identified subunits known to interact with $\mathrm{P} 2 \mathrm{X} 2$ or $\mathrm{P} 2 \mathrm{X} 5$, such as $\mathrm{P} 2 \mathrm{X} 3$ and P2X1, respectively (Lewis et al., 1995; Haines et al., 1999; Lê et al., 1999; Surprenant et al., 2000), and revealed P2X2 subunits as a new assembly partner of P2X5. In native tissue, $\mathrm{P} 2 \mathrm{X} 2$ and $\mathrm{P} 2 \mathrm{X} 5$ subunits were coimmunoprecipitated from brain and brainstem, and immunostaining colocalized the two proteins within specific subsets of neurons known to express P2X5 subunits (Collo et al., 1996). Interactions between $\mathrm{P} 2 \mathrm{X} 5$ and $\mathrm{P} 2 \mathrm{X} 2$ subunits enable bioluminescent resonance energy transfer, as well as hemi-YFP complementation and BRET/BiFC. These results strongly support that $\mathrm{P} 2 \mathrm{X} 2$ subunits associate with P2X5 within a heterotrimeric channel. It is unlikely that the energy transfer observed between these subunits results from nonspecific interactions since BRET signals between P2X2 and P2X5 were clearly saturable, and in parallel experiments there was no energy transfer between P2X2 and P2X4 subunits. Nevertheless, both energy transfer and fluorescence complementation could result from higher state oligomerization of receptor complexes, as demonstrated in the case of dopamine $\mathrm{D}_{2}$ receptors (Guo et al., 2008). Such FRETcompatible oligomeric interactions have also been described between $\mathrm{P} 2 \mathrm{X}$ receptors and different ligand-gated channels, for example between P2X2 and nicotinic channels (Khakh et al., 2005) or between P2X5 and ASIC3 (Birdsong et al., 2010). Atomic force microscopy has also revealed the existence of dimers of homotrimers between P2X4 receptors and either P2X2 or P2X7 receptors, suggesting oligomeric interactions between $\mathrm{P} 2 \mathrm{X}$ receptors (Antonio et al., 2011). However, as stated above, we found no evidence for specific BRET or BiFC between P2X2 and P2X4 subunits, supporting that the BRET observed between P2X subunits results exclusively from heterotrimeric assembly rather than from oligomeric interactions. This is further supported by our cross-linking experiments with BS3, which clearly demonstrate that P2X2 and P2X5 subunits only associate within a trimeric complex.

Trimeric $\mathrm{P} 2 \mathrm{X} 2 / 5$ receptors present two possible stoichiometries, $\mathrm{P} 2 \mathrm{X} 2 /(\mathrm{P} 2 \mathrm{X} 5)_{2}$ and $(\mathrm{P} 2 \mathrm{X} 2)_{2} / \mathrm{P} 2 \mathrm{X} 5$. These findings were established by measuring the energy transfer between one given luciferase-tagged subunit and two hemi-YFP tagged subunits of the second kind. This dual stoichiometry was also confirmed with a biochemical approach, by coexpressing Myc- and Cam-tagged subunits, although in these experiments, only one cameleon- 
A
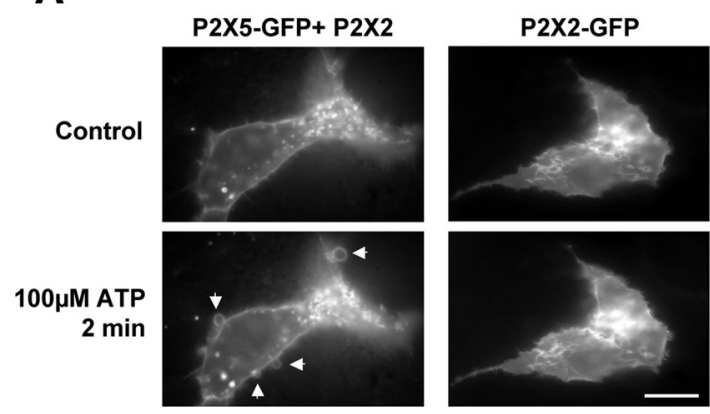

C

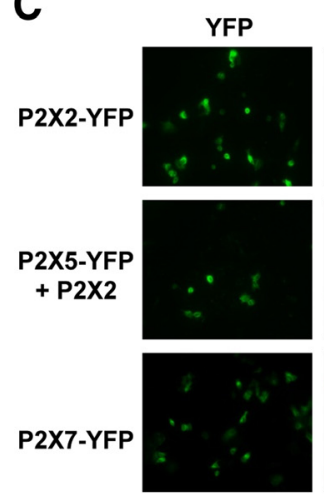

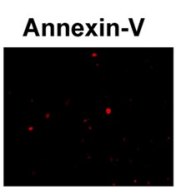
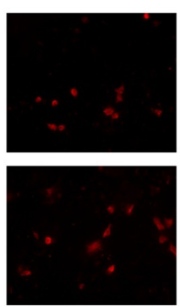

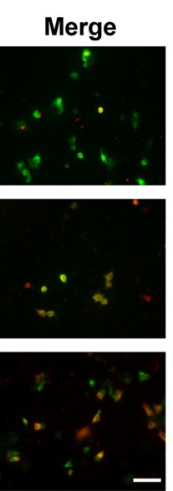

B

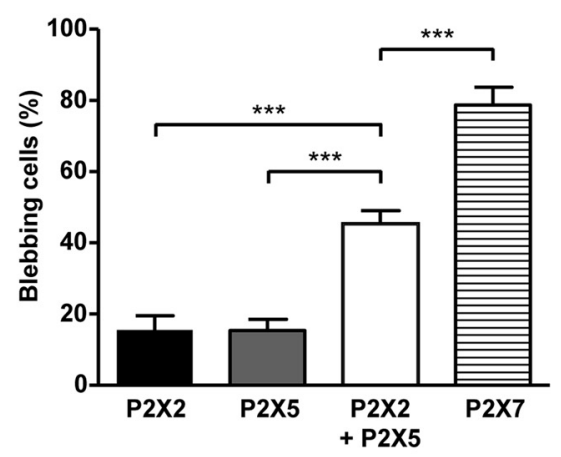

D

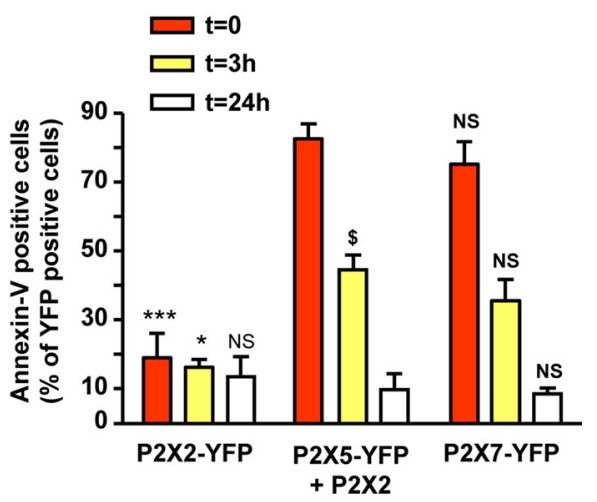

Figure 9. Activation of $\mathrm{P} 2 \mathrm{X} 2 / 5$ receptors mediates membrane blebbing and pseudo-apoptosis. $A, B, P 2 \times 2 / 5$ activation triggers membrane blebbing. $\boldsymbol{A}$, Representative fluorescence images of HEK cells expressing P2X2-GFP or P2X2 + P2X5-GFP 2 min after $100 \mu \mathrm{m}$ ATP stimulation. Arrows indicate ATP induced blebs. Scale bar, $10 \mu \mathrm{m}$. $\boldsymbol{B}$, Quantitative analysis of the percentage of blebbing cells expressing P2X2-GFP, P2X5-GFP, P2X2/5-GFP, or P2X7-GFP after stimulation with $100 \mu \mathrm{m}$ ATP ( 2 mm for P2X7) for 2 min. Results were normalized to the number of GFP-positive cells. Data are mean \pm SEM of $N=3$ independent experiments. ${ }^{* * *} p<0.005$, one-way ANOVA, followed by Bonferroni's multiple-comparison test. C, D, P2X2/5 receptor activation induces transient annexin-V exposure. C, HEK cells transfected with P2X2-YFP, P2X2 + P2X5-YFP, or P2X7-YFP were stimulated with $100 \mu \mathrm{m}$ ATP (500 $\mu \mathrm{m}$ for P2X7-YFP) and annexin-V staining was performed 5 min after the end of the stimulation. Scale bar, $50 \mu \mathrm{m}$. D. Analysis of annexin-V staining at 0, 3, or $24 \mathrm{~h}$ after ATP stimulation. Experiment was performed as in $C$, except that annexin-V staining was performed at the time indicated after ATP stimulation. In all panels, results were normalized to the number of YFP-positive cells. Data are mean \pm SEM, $n>30$ cells, $N=3$ experiments. ${ }^{*} p<0.05$, ${ }^{* * *} p<$ 0.005 ; N.S., not significant by comparison with P2X2/5 transfected cells at the same time point. ${ }^{\$} p<0.05$, comparison between P2X2/5-expressing cells at 0 and 3 h. One-way ANOVA, followed by Bonferroni's multiple-comparison test.

tagged subunit was incorporated into a receptor complex. However, this was equally observed for homomeric P2X 5 and P2X2, as well as heteromeric subunit assemblies. It is likely that, because of the size of the fusion partner, Cam-tagged subunits have either reduced expression efficiency or slower maturation, resulting in a lower efficacy of incorporation within trimers. Alternatively, channels associating two Cam-tagged subunits and one Myc could be present but remain undetected due to the low sensitivity of the anti-Myc antibody and the presence of a single Myc-tagged subunit within the complex. Dual stoichiometry has been reported for the assembly of P2X2 and P2X6 subunits, for which stoichiometry is influenced by the relative amount of each subunit (Barrera et al., 2007). Alternate stoichiometries have also previously been demonstrated for the pentameric assembly of nicotinic $\alpha 2 \beta 4$ channels (Moroni et al., 2008; Carbone et al., 2009). Whether these alternate assemblies of ligand-gated channels result from the heterologous expression system used, or are of physiological relevance, remains to be established.

P2X5 orthologues display considerable functional diversity. Bullfrog, chicken, and human homomeric P2X 5 receptors show robust expression in oocytes or mammalian cells (Jensik et al., 2001; Ruppelt et al., 2001; Bo et al., 2003) and display specific properties such as high chloride permeability, or, in the case of the full-length human isoform, a quasi-instantaneous NMDG permeability. This is in stark contrast to rodent homomeric P2X5 receptors, which are poorly functional (Collo et al., 1996; Cox et al., 2001). Our functional data, together with previous studies on P2X1/5 receptors (Haines et al., 1999; Lê et al., 1999; Surprenant et al., 2000), support the idea that rodent P2X5 subunits are auxiliary subunits, associating with $\mathrm{P} 2 \mathrm{X} 1, \mathrm{P} 2 \mathrm{X} 2$, and $\mathrm{P} 2 \mathrm{X} 4$ subunits to generate molecular diversity among $\mathrm{P} 2 \mathrm{X}$ receptors. Rat $\mathrm{P} 2 \mathrm{X} 2$ and P2X5 receptors, however, have similar pharmacology (North and Surprenant, 2000). Consistent with this, our pharmacological profiling shows that all of the agonists tested had similar efficacies at $\mathrm{P} 2 \mathrm{X} 2$ and $\mathrm{P} 2 \mathrm{X} 2 / 5$ receptors, although the potencies were significantly lower at $\mathrm{P} 2 \mathrm{X} 2 / 5$ receptors. Only BzATP displayed a much lower efficacy at $\mathrm{P} 2 \mathrm{X} 2 / 5$ receptors, which may be due to the lack of sensitivity of the rat homomeric $\mathrm{P} 2 \mathrm{X} 5$ receptor to BzATP (North and Surprenant, 2000). Rescue experiments using a trafficking mutant of either $\mathrm{P} 2 \mathrm{X} 2$ or $\mathrm{P} 2 \mathrm{X} 5$ subunits did not allow the unambiguous definition of the pharmacological profile of $\mathrm{P} 2 \mathrm{X} 2 / 5$ heteromers. These experiments, however, suggest that $(\mathrm{P} 2 \mathrm{X} 2)_{2} / \mathrm{P} 2 \mathrm{X} 5$ might be the only functional heteromer, since (1) P2X5 subunits are unable to functionally rescue P2X2K366A and (2) upon coexpression of P2X2 and P2X5-K372A subunits, BzATP potency is significantly lower than at P2X2. However, in this latter experiment, the presence of homomeric $\mathrm{P} 2 \mathrm{X} 2$ receptors prevented any precise pharmacological profiling.

Our immunohistochemical data are consistent with the expression of $\mathrm{P} 2 \mathrm{X} 2 / 5$ receptors in proprioceptive neurons of the 
mesencephalic trigeminal nucleus. Indeed, these neurons express P2X5 receptors (Collo et al., 1996; Cook et al., 1997), as well as $\mathrm{P} 2 \mathrm{X}$ receptors with a pharmacology differing from that of any recombinant homomeric or heteromeric receptors (Cook et al., 1997; Patel et al., 2001). Similarly, in sensory neurons, P2X2/5 receptors could contribute to the recently described P2Xmediated ASIC3 facilitation involved in the detection of muscle ischemia (Birdsong et al., 2010).

Similar to P2X7 receptors, P2X2 and P2X4 receptors can undergo time-dependent permeability changes, leading to significant permeability to NMDG (Khakh et al., 1999; Virginio et al., 1999b). P2X2/5- and P2X7-evoked conductances have some striking similarities. In oocytes, compared with $\mathrm{P} 2 \mathrm{X} 2$, the $\mathrm{P} 2 \mathrm{X} 2 / 5$-evoked NMDG conductance developed with a delayed onset and slower kinetics, was not saturable and poorly reversible, and displayed a complete loss of the initial inward rectification. P2X2/5-evoked sustained NMDG conductances were also observed in HEK cells, ruling out a cell-type dependent phenomenon. In addition, as described for P2X7 (Jiang et al., 2005), the P2X2/5 sustained NMDG conductance closes upon switching to sodium-containing extracellular solution. In HEK cells, P2X2/5 receptor-mediated Yo-Pro-1 uptake displayed slower kinetics as well as lower sensitivity to ATP, compared with $\mathrm{P} 2 \mathrm{X} 2$ receptors. Nevertheless, the absolute value of fluorescence was larger in cells transfected with $\mathrm{P} 2 \mathrm{X} 2 / 5$. Additionally, under physiological conditions, P2X2/5- and P2X7-evoked EtBr uptake shared common features not observed with $\mathrm{P} 2 \mathrm{X} 2$, mainly slow kinetics and an absence of saturation. Altogether, these data support the notion that activation of $\mathrm{P} 2 \mathrm{X} 2 / 5$ receptors triggers membrane permeabilization, a function thought to be uniquely associated with P2X7 receptors (Skaper et al., 2010). It remains to be determined whether NMDG and Yo-Pro-1 uptake are mediated by the same molecular mechanisms at $\mathrm{P} 2 \mathrm{X} 2$ and $\mathrm{P} 2 \mathrm{X} 2 / 5$ receptors. Our observation that the conformational motions of the cytoplasmic tail of $\mathrm{P} 2 \mathrm{X} 2 / 5$ receptor are undetectable by BRET might support two independent mechanisms.

$\mathrm{P} 2 \mathrm{X} 2 / 5$ receptors share other functional properties with the $\mathrm{P} 2 \mathrm{X} 7$ receptor, particularly its ability to trigger membrane blebbing (Morelli et al., 2003; Verhoef et al., 2003) and pseudoapoptosis (Virginio et al., 1999a; Mackenzie et al., 2005). Blebs are often associated with apoptosis; however, in the case of P2X7 receptors, short ATP stimulations trigger blebbing and plasma membrane PS flip that do not result in cell death (Mackenzie et al., 2005), a process qualified as pseudoapoptosis. $\mathrm{P} 2 \mathrm{X} 2 / 5$ receptor-induced blebbing displays similar features to P2X7. It is a reversible process observed under physiological conditions with an onset of $<20 \mathrm{~s}$, and is highly dynamic with blebs completely resorbing while new ones appear. Furthermore, activation of $\mathrm{P} 2 \mathrm{X} 2 / 5$ receptors also results in pseudoapoptosis, characterized by a reversible annexin- $\mathrm{V}$ exposure associated with an absence of cell death.

ATP-evoked Yo-Pro-1 uptake, blebbing, or apoptosis are widely considered to be specific signatures of P2X7 receptor activity. Our data establish that under physiological conditions, identical phenotypes can also result from activation of $\mathrm{P} 2 \mathrm{X} 2 / 5$ heteromeric receptors. In the nervous system and particularly in neurons, the expression of P2X7 receptors is somewhat controversial (Sim et al., 2004; Anderson and Nedergaard, 2006). It is thus conceivable that in these structures or cells, other $\mathrm{P} 2 \mathrm{X}$ receptors might contribute to cellular responses typically attributed to P2X7 receptors.

\section{References}

Anderson CM, Nedergaard M (2006) Emerging challenges of assigning $\mathrm{P} 2 \mathrm{X} 7$ receptor function and immunoreactivity in neurons. Trends Neurosci 29:257-262.
Antonio LS, Stewart AP, Xu XJ, Varanda WA, Murrell-Lagnado RD, Edwardson JM (2011) P2X4 receptors interact with both P2X2 and P2X7 receptors in the form of homotrimers. Br J Pharmacol 163:1069-1077.

Aschrafi A, Sadtler S, Niculescu C, Rettinger J, Schmalzing G (2004) Trimeric achitecture of homomeric $\mathrm{P} 2 \mathrm{X} 2$ and heteromeric $\mathrm{P} 2 \mathrm{X} 1+2$ receptor subtypes. J Mol Biol 342:333-343.

Ayoub MA, Maurel D, Binet V, Fink M, Prézeau L, Ansanay H, Pin JP (2007) Real-time analysis of agonist-induced activation of protease-activated receptor $1 /$ Galphail protein complex measured by bioluminescence resonance energy transfer in living cells. Mol Pharmacol 71:1329-1340.

Barrera NP, Henderson RM, Murrell-Lagnado RD, Edwardson JM (2007) The stoichiometry of P2X2/6 receptor heteromers depends on relative subunit expression levels. Biophys J 93:505-512.

Birdsong WT, Fierro L, Williams FG, Spelta V, Naves LA, Knowles M, MarshHaffner J, Adelman JP, Almers W, Elde RP, McCleskey EW (2010) Sensing muscle ischemia: coincident detection of acid and ATP via interplay of two ion channels. Neuron 68:739-749.

Bo X, Jiang LH, Wilson HL, Kim M, Burnstock G, Surprenant A, North RA (2003) Pharmacological and biophysical properties of the human P2X5 receptor. Mol Pharmacol 63:1407-1416.

Brederson JD, Jarvis MF (2008) Homomeric and heteromeric P2X3 receptors in peripheral sensory neurons. Curr Opin Investig Drugs 9:716-725.

Carbone AL, Moroni M, Groot-Kormelink PJ, Bermudez I (2009) Pentameric concatenated (alpha4)(2)(beta2)(3) and (alpha4)(3)(beta2)(2) nicotinic acetylcholine receptors: subunit arrangement determines functional expression. Br J Pharmacol 156:970-981.

Chaumont S, Jiang LH, Penna A, North RA, Rassendren F (2004) Identification of a trafficking motif involved in the stabilization and polarization of P2X receptors. J Biol Chem 279:29628-29638.

Chaumont S, Compan V, Toulme E, Richler E, Housley GD, Rassendren F, Khakh BS (2008) Regulation of $\mathrm{P} 2 \mathrm{X} 2$ receptors by the neuronal calcium sensor VILIP1. Sci Signal 1: ra8.

Collo G, North RA, Kawashima E, Merlo-Pich E, Neidhart S, Surprenant A, Buell G (1996) Cloning OF P2X5 and P2X6 receptors and the distribution and properties of an extended family of ATP-gated ion channels. J Neurosci 16:2495-2507.

Cook SP, Vulchanova L, Hargreaves KM, Elde R, McCleskey EW (1997) Distinct ATP receptors on pain-sensing and stretch-sensing neurons. Nature 387:505-508.

Cox JA, Barmina O, Voigt MM (2001) Gene structure, chromosomal localization, cDNA cloning and expression of the mouse ATP-gated ionotropic receptor P2X5 subunit. Gene 270:145-152.

Fisher JA, Girdler G, Khakh BS (2004) Time-resolved measurement of statespecific P2X2 ion channel cytosolic gating motions. J Neurosci 24:10475-10487.

Guo W, Urizar E, Kralikova M, Mobarec JC, Shi L, Filizola M, Javitch JA (2008) Dopamine D2 receptors form higher order oligomers at physiological expression levels. EMBO J 27:2293-2304.

Haines WR, Torres GE, Voigt MM, Egan TM (1999) Properties of the novel ATP-gated ionotropic receptor composed of the P2X(1) and P2X(5) isoforms. Mol Pharmacol 56:720-727.

Héroux M, Hogue M, Lemieux S, Bouvier M (2007) Functional calcitonin gene-related peptide receptors are formed by the asymmetric assembly of a calcitonin receptor-like receptor homo-oligomer and a monomer of receptor activity-modifying protein-1. J Biol Chem 282:31610-31620.

Jensik PJ, Holbird D, Collard MW, Cox TC (2001) Cloning and characterization of a functional P2X receptor from larval bullfrog skin. Am J Physiol Cell Physiol 281:C954-962.

Jiang LH, Rassendren F, Mackenzie A, Zhang YH, Surprenant A, North RA (2005) N-methyl-D-glucamine and propidium dyes utilize different permeation pathways at rat P2X(7) receptors. Am J Physiol Cell Physiol 289:C1295-302.

Kawate T, Michel JC, Birdsong WT, Gouaux E (2009) Crystal structure of the ATP-gated P2X(4) ion channel in the closed state. Nature 460:592-598.

Khakh BS, Bao XR, Labarca C, Lester HA (1999) Neuronal P2X transmittergated cation channels change their ion selectivity in seconds. Nat Neurosci 2:322-330.

Khakh BS, Fisher JA, Nashmi R, Bowser DN, Lester HA (2005) An angstrom scale interaction between plasma membrane ATP-gated P2X2 and alpha4beta2 nicotinic channels measured with fluorescence resonance 
energy transfer and total internal reflection fluorescence microscopy. J Neurosci 25:6911-6920.

Kotnis S, Bingham B, Vasilyev DV, Miller SW, Bai Y, Yeola S, Chanda PK, Bowlby MR, Kaftan EJ, Samad TA, Whiteside GT (2010) Genetic and functional analysis of human P2X5 reveals a distinct pattern of exon 10 polymorphism with predominant expression of the nonfunctional receptor isoform. Mol Pharmacol 77:953-960.

Lalo U, Pankratov Y, Wichert SP, Rossner MJ, North RA, Kirchhoff F, Verkhratsky A (2008) P2X1 and P2X5 subunits form the functional P2X receptor in mouse cortical astrocytes. J Neurosci 28:5473-5480.

Lê KT, Boué-Grabot E, Archambault V, Séguéla P (1999) Functional and biochemical evidence for heteromeric ATP-gated channels composed of P2X1 and P2X5 subunits. J Biol Chem 274:15415-15419.

Lewis C, Neidhart S, Holy C, North RA, Buell G, Surprenant A (1995) Coexpression of $\mathrm{P} 2 \mathrm{X} 2$ and $\mathrm{P} 2 \mathrm{X} 3$ receptor subunits can account for ATPgated currents in sensory neurons. Nature 377:432-435.

Mackenzie AB, Young MT, Adinolfi E, Surprenant A (2005) Pseudoapoptosis induced by brief activation of ATP-gated P2X7 receptors. J Biol Chem 280:33968-33976.

Morelli A, Chiozzi P, Chiesa A, Ferrari D, Sanz JM, Falzoni S, Pinton P, Rizzuto R, Olson MF, Di Virgilio F (2003) Extracellular ATP causes ROCK I-dependent bleb formation in P2X7-transfected HEK293 cells. Mol Biol Cell 14:2655-2664.

Moroni M, Vijayan R, Carbone A, Zwart R, Biggin PC, Bermudez I (2008) Non-agonist-binding subunit interfaces confer distinct functional signatures to the alternate stoichiometries of the alpha4beta2 nicotinic receptor: an alpha4-alpha4 interface is required for $\mathrm{Zn}^{2+}$ potentiation. J Neurosci 28:6884-6894.

Nicke A, Bäumert HG, Rettinger J, Eichele A, Lambrecht G, Mutschler E, Schmalzing G (1998) P2X1 and P2X3 receptors form stable trimers: a novel structural motif of ligand-gated ion channels. EMBO J 17:3016-3028.

North RA, Surprenant A (2000) Pharmacology of cloned P2X receptors. Annu Rev Pharmacol Toxicol 40:563-580.

Patel MK, Khakh BS, Henderson G (2001) Properties of native P2X receptors in rat trigeminal mesencephalic nucleus neurones: lack of correlation with known, heterologously expressed P2X receptors. Neuropharmacology 40:96-105.

Radford KM, Virginio C, Surprenant A, North RA, Kawashima E (1997) Baculovirus expression provides direct evidence for heteromeric assembly of P2X2 and P2X3 receptors. J Neurosci 17:6529-6533.

Ramjeesingh M, Huan LJ, Garami E, Bear CE (1999) Novel method for evaluation of the oligomeric structure of membrane proteins. Biochem J 342:119-123.
Richler E, Chaumont S, Shigetomi E, Sagasti A, Khakh BS (2008) Tracking transmitter-gated P2X cation channel activation in vitro and in vivo. Nat Methods 5:87-93.

Roberts JA, Vial C, Digby HR, Agboh KC, Wen H, Atterbury-Thomas A, Evans RJ (2006) Molecular properties of P2X receptors. Pflugers Arch 452:486-500.

Ruppelt A, Ma W, Borchardt K, Silberberg SD, Soto F (2001) Genomic structure, developmental distribution and functional properties of the chicken P2X(5) receptor. J Neurochem 77:1256-1265.

Schwiebert LM, Rice WC, Kudlow BA, Taylor AL, Schwiebert EM (2002) Extracellular ATP signaling and P2X nucleotide receptors in monolayers of primary human vascular endothelial cells. Am J Physiol Cell Physiol 282:C289-301.

Sim JA, Young MT, Sung HY, North RA, Surprenant A (2004) Reanalysis of P2X7 receptor expression in rodent brain. J Neurosci 24:6307-6314.

Skaper SD, Debetto P, Giusti P (2010) The P2X7 purinergic receptor: from physiology to neurological disorders. FASEB J 24:337-345.

Surprenant A, North RA (2009) Signaling at purinergic P2X receptors. Annu Rev Physiol 71:333-359.

Surprenant A, Rassendren F, Kawashima E, North RA, Buell G (1996) The cytolytic P2Z receptor for extracellular ATP identified as a P2X receptor (P2X7). Science 272:735-738.

Surprenant A, Schneider DA, Wilson HL, Galligan JJ, North RA (2000) Functional properties of heteromeric $\mathrm{P} 2 \mathrm{X}(1 / 5)$ receptors expressed in HEK cells and excitatory junction potentials in guinea-pig submucosal arterioles. J Auton Nerv Syst 81:249-263.

Taly A, Corringer PJ, Guedin D, Lestage P, Changeux JP (2009) Nicotinic receptors: allosteric transitions and therapeutic targets in the nervous system. Nat Rev Drug Discov 8:733-750.

Torres GE, Egan TM, Voigt MM (1999) Hetero-oligomeric assembly of P2X receptor subunits. Specificities exist with regard to possible partners. J Biol Chem 274:6653-6659.

Verhoef PA, Estacion M, Schilling W, Dubyak GR (2003) P2X7 receptordependent blebbing and the activation of Rho-effector kinases, caspases, and IL-1 beta release. J Immunol 170:5728-5738.

Virginio C, MacKenzie A, North RA, Surprenant A (1999a) Kinetics of cell lysis, dye uptake and permeability changes in cells expressing the rat P2X7 receptor. J Physiol 519:335-346.

Virginio C, MacKenzie A, Rassendren FA, North RA, Surprenant A (1999b) Pore dilation of neuronal P2X receptor channels. Nat Neurosci 2:315321. 